
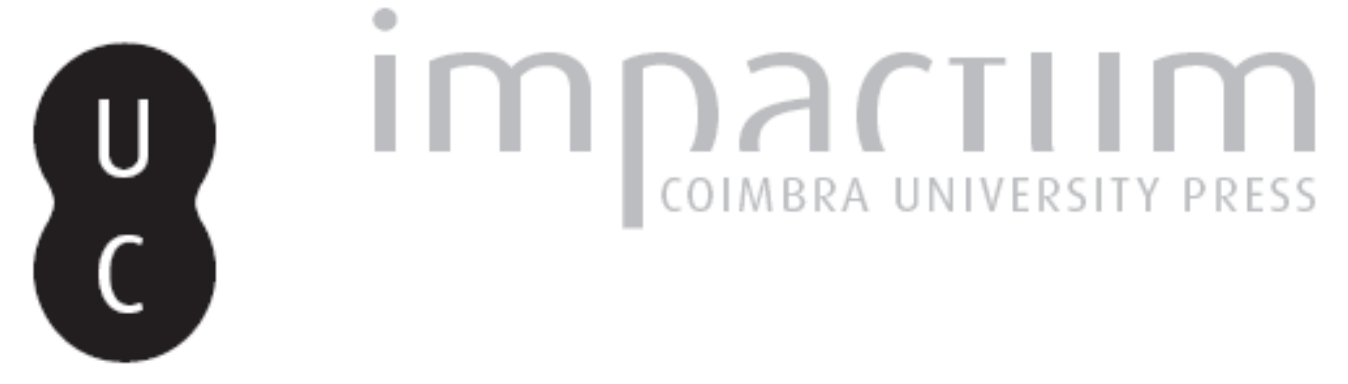

\title{
Artefactos romanos e post-romanos de S. Cucufate
}

Autor(es): $\quad$ Ponte, Salete da

Publicado por: Imprensa da Universidade de Coimbra

URL persistente:

URI:http://hdl.handle.net/10316.2/45601

DOI:

DOI:https://dx.doi.org/10.14195/1647-8657_26_7

Accessed : $\quad$ 26-Apr-2023 12:13:56

A navegação consulta e descarregamento dos títulos inseridos nas Bibliotecas Digitais UC Digitalis, UC Pombalina e UC Impactum, pressupõem a aceitação plena e sem reservas dos Termos e Condições de Uso destas Bibliotecas Digitais, disponíveis em https://digitalis.uc.pt/pt-pt/termos.

Conforme exposto nos referidos Termos e Condições de Uso, o descarregamento de títulos de acesso restrito requer uma licença válida de autorização devendo o utilizador aceder ao(s) documento(s) a partir de um endereço de IP da instituição detentora da supramencionada licença.

Ao utilizador é apenas permitido o descarregamento para uso pessoal, pelo que o emprego do(s) título(s) descarregado(s) para outro fim, designadamente comercial, carece de autorização do respetivo autor ou editor da obra.

Na medida em que todas as obras da UC Digitalis se encontram protegidas pelo Código do Direito de Autor e Direitos Conexos e demais legislação aplicável, toda a cópia, parcial ou total, deste documento, nos casos em que é legalmente admitida, deverá conter ou fazer-se acompanhar por este aviso.

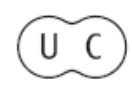


FACULDADE DE LETRAS

INSTITUTO DE ARQUEOLOGIA

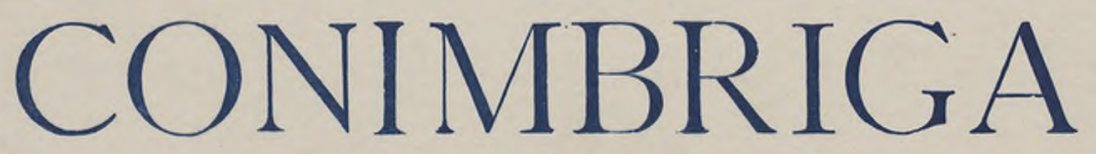

VOLUME XXVI

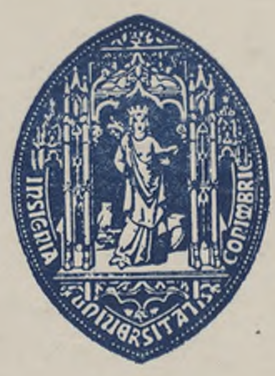

UNIVERSIDADE DE COIMBRA

1987 
Professora-Coordenadora da Escola Superior de Tecnologia de Tomar

\section{ARTEFACTOS ROMANOS E POST-ROMANOS DE S. CUCUFATE «Conimbriga», XXVI (1987), p. 133-165}

Resumo: Os autores do relatório de escavações da Villa romana de

S. Cucufate seleccionaran ${ }^{\wedge}$ um reduzido número de objectos metálicos e de osso, para publicação nessa obra.

Deixaram de lado largas dezenas de objectos pouco significativos para a reconstituição da vida económica do fundus, mas merecedor de publicação nesta revista. Incluímos, assim, neste trabalho, 164 objectos, sendo 138 da época romana e 26 provenientes de ocupação da Villa por um Convento que permaneceu desde meados do séc. XIII até ao séc. XVI.

RÉsumé: Les auteurs du rapport de fouilles de la Villa romaine de S.

Cucufate ont choisi un nombre assez réduit d'exemplaires métaliques et d'os, pour la publication dans cet oeuvre. Ils ont laissé de côté beaucoup d'objects peu significatifs pour la reconstituition de la vie économique du fundus, mais digne de publication dans cette revue.

L'article fait l'inventaire de 164 exemplaires, desquels 138 de l'époque romaine et 26 provenant de l'occupation de la Villa par un Couvent qui a été occupé depuis e XIIİ̀me jusqu'au XVIème siècle. 
(Página deixada propositadamente em branco) 


\section{ARTEFACTOS ROMANOS E FOST-ROMANOS DE S. CUCUFATE}

Introdução

Os autores do relatório de escavações da villa romana de S. Cucufate seleccionaram, para publicação nessa obra, um reduzido número de objectos metálicos ou de osso, mais directamente relacionados com a exploração agrária da villa ou com a sua actividade industriai. Ficaram de lado largas dezenas de objectos, decerto pouco significativos para a reconstituição da vida econòmica do fundus, mas todavia merecedores de publicação, mormente em Portugal. São, com efeito, ainda muito poucos os objectos de metal ou osso da época romana publicados no nosso país. Justifica-se, assim, por enquanto, a apresentação integral ou, pelo menos, sem critérios de selecção demasiadamente exigentes, do espólio metálico ou de osso encontrado em escavações. Tempo virá em que, conhecida a variedade e tipologia dos objectos da vida quotidiana romana, se tornará inútil a reprodução ad nauseam dos achados. Resolvemos, por isso, e aliás de acordo com os escavadores, apresentar tudo quanto nos pareceu significativo num artigo que constitui complemento daquele relatório.

Incluímos aqui 138 objectos da época romana. A villa foi, porém, na Idade Média, ocupada por um convento que aí permaneceu desde meados do séc. xm até ao séc. xvi. Do espólio correspondente a esta ocupação, aliás pouco abundante, seleccionámos 26 objectos. 


\section{Artefactos romanos}

\section{Instrumentos de fiação e de costura}

A fiação e a costura eram, na época romana, actividades caseiras. S. Cucufate forneceu, no entanto, poucos objectos de fiação: apenas duas fusaiolas (n. os 1-2). Quanto a instrumentos utilizados na costura, recolheram-se diversas agulhas, de que publicamos aqui uma selecção (n. $\left.{ }^{\text {s }} 3-14\right)$.

1. Fusaiola. Argila. Diâm. $28 \mathrm{~mm}$. Alt. $21 \mathrm{~mm}$. Forma bicónica, de cones iguais e base plana. CUC.84. (S/E).

2. Id. Osso. Diâm. $27 \mathrm{~mm}$. Alt. $5 \mathrm{~mm}$. Forma cónica e base plana. CUC.83.XX.29(3).

3. Agulha. Bronze. Compr. $54 \mathrm{~mm}$. De forma adelgaçada e de orla superior arredondada. Orifício longo e ovalado. Haste de secção arredondada. CUC.82.XX.3(3).

4. Id. Compr. $63 \mathrm{~mm}$. Semelhante à anterior, estando dobrada junto à cabeça adelgaçada. CUC.82.XX.7(4).

5. Id. Compr. $75 \mathrm{~mm}$. De maiores proporções, é semelhante aos dois exemplares anteriores. CUC.82.XX.3(3).

6. Id. Compr. $85 \mathrm{~mm}$. É semelhante à anterior, mas de maiores proporções. CUC.82.XX.8(3).

7. Id. Compr. $95 \mathrm{~mm}$. A parte inferior da haste está ligeiramente dobrada. CUC.84.VA.21 Banq.Sul(3).

8. Id. Compr. $95 \mathrm{~mm}$. A haste encurva-se para a direita. CUC.82.XX. $3(3)$.

9. Id. Compr. $70 \mathrm{~mm}$. Haste e cabeça de secção quadrangular. Orifício rasgado e ovalado. CUC.82.XX.3(3).

10. Id. Compr. $94 \mathrm{~mm}$. Haste e cabeça espalmadas, de secção rectangular. O topo da cabeça espalmada é horizontal. Orifício rasgado e ovalado. CUC.86. Limpeza do sector sul do peristilo.

II. Id. Osso. Compr. $62 \mathrm{~mm}$. Cabeça triangular e espatulada com ranhura imperfeita em 8, ladeada de círculos incisos. CUC.80. VIII.26(4b). 
12. Id. Compr. $36 \mathrm{~mm}$. É semelhante ao exemplar anterior, encontrando-se bastante incompleta. CUC.79.XIV.7(1).

13. Id. Compr. $39 \mathrm{~mm}$. Semelhante aos anteriores, mas sem qualquer decoração. CUC.81.XIV.18(3).

14. Id. Compr. $111 \mathrm{~mm}$. Cabeça bicónica e haste de secção circular. Ranhura em oito.CUC.85.S2(4).

\section{Objectos de adorno e de toilette}

Os n. os 15-20 correspondem a fíbulas. A primeira cabe no tipo transmontano caracterizado por J. Fortes ${ }^{\wedge}$ ), tipo que coincide com o $4 \mathrm{~h}$ de Schule. Distingue-se dos restantes exemplares de La Tène I pela decoração do arco, pelo perfil do pé encurvado e pela mola bilateral $\left(^{2}\right)$. Situa-se entre o séc. iv a. C. e o séc. i d. C. Os paralelos de Conimbriga $\left({ }^{3}\right)$ e do Monte Mozinho $\left({ }^{4}\right)$ permitem datar a fíbula de S. Cucufate dos finais do séc. i d. C.

As formas dos n.os 16-17 são comuns na Gália romana. Pertencem ao grupo de «fíbulas de charneira e arco triangular» (5). Datam da segunda metade do séc. i a. C.-inícios do i d. C., prolongando-se até ao período pré-flaviano nalguns sítios romanos $\left(^{(}\right)$.

Os n.os 18-20 enquadram-se basicamente no tipo $17 \mathrm{C}$ de Camulodunum, vulgarmente conhecido por «Aucissa» $\left({ }^{7}\right)$. Esta

(h Cfr. Fortes (J.), as fibulas do noroeste da Península, «Portugália», II, Porto, 1905-1908, p. 15-33 (p. 19-20).

(2) Cf. Alarcão (A. M. e J.), Étienne (R.) e Ponte (S.), Trouvailles Diverses-Conclusions Générales, (Fouilles de Conimbriga, VII), Paris, 1979, p. 115.

(3) Cf. id., ibidem, p. 115.

(4) Cf. Ferreira de Almeida (C. A.), Escavações no Monte Mozinho, (1975-1976), II, Penafiel, 1977, p. 16.

$\left(^{5}\right)$ Cf. Fouilles de Conimbriga, VII, p. 118.

(6) Cf. id., ibidem, p. 119, fig. 47.

$\left.{ }^{7}\right)$ Cf. Ponte (S. da), Fíbulas de sítios a norte do rio Douro, «Lucerna. Número extraordinàrio», Porto, 1984, p. 119. 
modalidade fixa-se entre o período claudiano e o flaviano-trajánico $\left({ }^{8}\right)$.

Os anéis são bastante simples e não têm, na sua maioria, qualquer decoração. Exceptuam-se os anéis de aro fitiforme (n.os 21-24), que apresentam uma decoração em ziguezague (n. ${ }^{\text {s }}$ 21-22), caneluras verticais (n. $\left.{ }^{\circ} 24\right)$ ou finas ranhuras longitudinais (n. ${ }^{\circ} 23$ e 31 ) executadas por cinzel ou punção. Os anéis com as extremidades sobrepostas (n. ${ }^{\text {os }}$ 25-29) formam ou não uma espiral. O n. ${ }^{\circ} 30$ apresenta também um aro fitiforme, cujas extremidades abertas estavam unidas por meio de solda. Estas formas provêm já da época helenística, sendo frequentes em vários sítios romanos $\left({ }^{9}\right)$. Os modelos de Fishbourne datam do séc. I-II d. C. $\left({ }^{10}\right)$. O n. ${ }^{\circ} 31$ é um anel de mesa com as extremidades abertas, mas em osso (chifre). Este exemplar deveria ter pertencido a uma criança. Esta modalidade ocorre com frequência entre os finais do séc. $n$ e o séc. IV d. C. ( ${ }^{\mathrm{n}}$ ).

Os braceletes de aro aberto (n. ${ }^{\circ} 32$ ) e os de fecho em gancho (n. ${ }^{\circ} 33$ ) são muito frequentes no período romano, ainda que estas formas apareçam já em níveis da 2. ${ }^{a}$ Idade do Ferro (12). A forma de aro aberto aparece, contudo, em níveis visigóticos $\left({ }^{13}\right)$. O modelo de fecho em gancho ocorre nos sécs. II-III d. C. $\left({ }^{14}\right)$. Os exemplares de S. Cucufate (n. ${ }^{\text {s } 32-33)}$ deveriam, pelo seu tamanho, ter pertencido a crianças.

$\left.{ }^{8}\right)$ Cf. id., ibidem, p. 121. Há um outro exemplar achado no Monte Manuel Galo (Mértola), semelhante aos de Conimbriga e de S. Cucufate (cf. Manuel Maia, Fortaleza romana do Monte Manuel Galo (Mértola), «Actas do III Congresso Nacional de Arqueologia», Porto, 1974, p. 325-332; cf. Ponte (Sálete da), Nove fibulas provenientes do distrito de Beja, comunicação apresentada no «II Encontro de Arqueologia do Baixo Alentejo-Castro Verde», (15-17 Abril, 1988).

$\left({ }^{9}\right)$ Cf. Fouilles de Conimbriga, VII, n. 133-134; Cf. Cunliffe (Barry), Excavations at Fishbourne 1961-1969, Leeds, 1971 (2), p. 108, fig. 41, n. ${ }^{\circ}$ 51-52

(10) Cf. Cunliffe (B.), op. cit., p. 107, fig. 51-52.

(u) Cf. França (Elsa Ávila), Anéis, braceletes e brincos de Conimbriga, «Conimbriga», 8, 1969, p. 17-64 (p. 19).

(12) Cf. id., ibidem, p. 55.

(13) Cf. Fouilles de Conimbriga, VII, p. 140.

(14) Cf. Cunliffe (B.), op. cit., p. 107, fig. 41, n. 47. 
Os brincos, de forma simples ou complexa, eram adorno comum das mulheres romanas. Os n.os 34-36 pertencem ao grupo de brincos anelares com pendentes (pérolas ou pedras preciosas). $\mathrm{O}$ aro é fino e o fecho, em gancho. Estes modelos aparecem com frequência nos sécs. i-ii d. C. $\left({ }^{15}\right)$. Os n. ${ }^{\text {os }}$ 37-38 são modelos tipicamente visigóticos $\left({ }^{16}\right)$. O primeiro teria a enriquecê-lo um pingente fixo à argolinha soldada ao aro. $\mathrm{O}$ n. ${ }^{\circ} 38$ é de prata; pelas dimensões reduzidas, teria pertencido a uma criança. A decoração em balaustre ou anelar de uma das extremidades do aro constitui uma das características marcantes dos brincos visigóticos.

Os quatro alfinetes de cabelo (n.os 39-42) correspondem a formas muito simples, sendo um de bronze e os restantes, de osso. $\mathrm{O}$ n. ${ }^{\circ} 39$ é um alfinete de cabeça esférica, independente da haste. Corresponde à forma 48 de Beckmann, que o autor data entre o séc. $\mathrm{i}$ d. C. e a $1 .{ }^{a}$ metade do séc. $\mathrm{n}$ d. C. $\left({ }^{17}\right)$. $\mathrm{O}$ n. ${ }^{\circ} 40$ apresenta uma cabeça bicónica, correspondente ao tipo 195 de Beckmann, que o data do séc. $n$ d. C. $\left({ }^{18}\right)$. Os n. ${ }^{\text {os } 41}$ e 42 apresentam cabeças, respectivamente, em diamante e em cebola. Esta variedade de alfinetes aparece em vários sítios romanos, sendo o $\mathrm{n} .{ }^{\circ} 40$ muito frequente em Conimbriga, desde o séc. i ao iv d. C. $\left({ }^{19}\right)$.

Os objectos de toilette incluem uma lâmina de barbear (n. ${ }^{\circ} 43$ ), pinças (n.os 44-45) e quatro sondas (n.os 46-49). Rigorosamente, a lâmina e as pinças tanto podem ter servido para barbear e depilar como para operações cirúrgicas. As pinças cirúrgicas removiam triquíases e tumores $\left({ }^{20}\right)$ e para este fim pode ter sido usada a peça $n .^{\circ} 45$. É muito semelhante aos exemplares representados em pinturas murais e aos achados na Casa do Cirurgião, em Pompeios $\left({ }^{21}\right)$.

(15) Cf. França (E. A.), art. cit., p. 29 e 46.

(16) Cf. Fouilles de Conimbriga, VII, p. 142.

${ }^{17}$ ) Cf. Beckmann (B.), Studien uber die Metallnadeln der römischen Kaiserzeit im freien Germanien, «Saalburg-Jahrbuch», 23, 1966, p. 7-100 (p. 23, Est. 2, n. ${ }^{\circ} 48$ ).

(18) Cf. id., ibidem, p. 23

$\left({ }^{19 j}\right.$ Cf. Fouilles de Conimbriga, VII, p. 129, Est. XXX, 130.

$\left.{ }^{20}\right)$ Cf. Milne (John Stewart), et allii, Surgicalinstruments in Greek and Roman Times, Chicago, 1976, p. 90-92.

(21) Cf. Penso (Giuseppe), La médecine romaine, Paris, 1984, p. 396, fig. 206 e p. 403 , fig. 208. 
As sondas (n.os 46-49), ainda que frequentemente utilizadas como instrumentos de toilette $\left({ }^{22}\right)$, podem também ter servido como instrumentos cirúrgicos $\left({ }^{23}\right)$. O escritor Celso, no livro De re medica, refere-se a elas (cyathiscomelae) como instrumentos apropriados para a preparação e aplicação de medicamentos, de pomadas e de perfumes $\left({ }^{24}\right)$.

É o caso do nosso exemplar n. ${ }^{\circ} 46$. As outras sondas (n. ${ }^{\text {os }} 47-49$ ) correspondentes ao cyathiscomela e ao specillum, seriam usadas nos cuidados de limpeza e de tratamento dos ouvidos e dentes (25). Conhecemos numerosos exemplares recolhidos em vários sítios romanos $(26)$.

15. Fibula de tipo transmontano (4h Schule). Bronze. Compr. $37 \mathrm{~mm}$. Alt. $24 \mathrm{~mm}$. Arco em forma de naveta invertida com decoração anelar em ambas as extremidades. Pé curto e triangular. GUG. 84.XV.41 Banq. Sul(5).

16. Fibula de tipo «charneira e arco triangular». Bronze. Compr. $52 \mathrm{~mm}$. Alt. $10 \mathrm{~mm}$. Arco de feição triangular decorado longitudinalmente por um motivo em espinha. Pé coroado por um botão cónico e descanso triangular. CUG.81.XIII.6/7(2).

17. Id. Compr. $75 \mathrm{~mm}$. Alt. $16 \mathrm{~mm}$. Semelhante ao anterior, mas de maiores proporções. CUC.84.XV.46(3).

(22) Cf. Rin A (Emilie), Römisches Toilettgerat und medizinische Instrumente aus August und Kaiseraugst (Forschungen in August, 6), August, 1986, p. 102-103.

(23) Cf. Milne (J. S.), op. cit, p. 51-89 (p. 61-68) e Riha (E.), op. cit., p. 64-65. Esta autora integra os exemplares semelhantes ao $\mathrm{n} .^{\circ} 44$, na variante $\mathrm{A}$.

(24) Cf. Rina (E.), op. cit., p. 64-65; Cf. Penso (G.), op. cit., p. 462; Cf. Milne (J. S.), op. cit., p. 63-68; Cf. Dorig (José), Art Antique (Collections privées de Suisse Romande), Génova, 1975, fig. 366, n. ${ }^{\circ} 4$ e n. ${ }^{\circ} 20$.

(25) Cf. Dorig (J.), op. cit., p. 366; Milne (J. S.), op. cit., p. 64; Rina (E.), op. cit., p. 72-73.

${ }^{26}$ Cf. Fouilles de Conimbriga, VII, p, 146, Est. XXXVI, n. ${ }^{\circ} 270-272$; Frere (Sheppard), Verulamium Excavations (Reports of the Research Committee of the Society of Antiquaries of London, n. ${ }^{\circ}$ XXVIII), Oxford, 1972, p. 124, fig. 35, n. 72 (é semelhante ao nosso exemplar n. ${ }^{\circ} 44$. O autor data-o de 270-275 d.C.); Rina (E.), op. cit., p. 73, Est. 54, n. ${ }^{\circ}$ 597. A autora integra-o na variante $\mathrm{G}$, datando-o do $3 .^{\circ}$ quartel do séc. i d.C. 
18. Fíbula de tipo Aucissa (17G Gamul.). Bronze e ferro. Gompr. $34 \mathrm{~mm}$. Alt. $25 \mathrm{~mm}$. O arco semicircular, de secção losangonal, é decorado por um simples encordoado; o mesmo motivo repete-se na placa de feição rectangular, com chanfros laterais. Pé com botão cónico e descanso triangular. Conserva parte do eixo, em ferro. CUC.84.XV.41.Banq. Sul(5).

19. Id. Gompr. $51 \mathrm{~mm}$. Alt. $34 \mathrm{~mm}$. Semelhante ao anterior. GUG. 84.T4(1).

20. Id. Gompr. $56 \mathrm{~mm}$. Alt. $33 \mathrm{~mm}$. Peça semelhante aos dois exemplares anteriores. CUC.83.XX.35.Banq.Sul(2).

21. Anel. Bronze. Diâm. $17 \mathrm{~mm}$. Aro muito fino decorado na orla com incisões em ziguezague. CUC.82.XX.2(3).

22. Id. Diâm. $16 \mathrm{~mm}$. Semelhante ao anterior, mas com a decoração incisa bastante gasta. CUC.82.XX.2(3).

23. Id. Diâm. $18 \mathrm{~mm}$. Aro circular sublinhado por duas finas ranhuras. CUC.84.XXIV.(S/E).

24. Id. Diâm. $23 \mathrm{~mm}$. Aro semelhante aos exemplares anteriores, apresentando caneluras verticais intervaladas. CUC.82.XX.7(1).

25. Id. Diâm. $18 \mathrm{~mm}$. Aro muito fino com as extremidades abertas e ligeiramente sobrepostas. CUC.82.XX.44(4).

26. Id. Diâm. $19 \mathrm{~mm}$. Aro oval, de secção semicircular com as extremidades sobrepostas. CUC.80.VIII.20(2) sepult.

27. Id. Diâm. $15 \mathrm{~mm}$. Aro fitiforme com as extremidades sobrepostas, formando uma espiral. GUG.82.XX.2(3).

28. Id. Diâm. $21 \mathrm{~mm}$. Semelhante ao anterior, mas de maiores proporções. CUG.82. XIV. 33(6).

29. Id. Diâm. 21 mm. Semelhante ao anterior. CUG.82.XX.2(3).

30. Id. Diâm. $22 \mathrm{~mm}$. Aro aberto fitiforme e largo, com as extremidades sobrepostas e unidas por meio de solda. CUC.84.V.15. Banq. Sul(2).

31. Id. Osso (chifre). Dim.: $20 \times 15 \mathrm{~mm}$. Aro aberto em D e com mesa plana. É decorado com uma ranhura longitudinal. CUG.83.XXI.24. Banq. Sul(3). 
32. Bracelete. Bronze. Diâm. $48 \mathrm{~mm}$. Aro circular e aberto. CUC. 80.S 15C(7).

33. Id. Diâm. aprox. $52 \mathrm{~mm}$. Aro fino bastante torcido com os extremos terminados em gancho. CUC.84.XV.A6(3).

34. Brinco. Bronze. Diâm. $18 \mathrm{~mm}$. Aro muito fino, com os extremos em espiral e sobrepostos, com fecho em gancho. Pingente formado por urna esfera e duas contas de vidro de cor verde esmeralda. GUC. 80. VII 1.20(2).

35-36. Par de brincos. Ouro. Diâm. $16 \mathrm{~mm}$. Aro muito fino, circular com fecho em gancho. CUC.86.S1.T4.

37. Brinco. Bronze. Diâm. $30 \mathrm{~mm}$. Aro fino, circular, aberto com um dos extremos terminado em ponta e o outro em balaustre. Orla exterior com uma pequena argola de suspensão que àquela se une por meio de solda. CUC.86.S7.Tl.

38. Id. Prata. Diâm. $18 \mathrm{~mm}$. Aro circular com um dos extremos terminado em ponta e o outro num motivo anelar. CUC.83.VIII.

$23 / 24(2)$.

39. Alfinete. Bronze. Alt. $60 \mathrm{~mm}$. Cabeça esférica independente, formada por um fio enrolado em espiral. CUC.81.VIII.17(2).

40. Id. Osso. Alt. $50 \mathrm{~mm}$. Cabeça bicónica, e cones iguais. Haste de secção circular. CUC.81.VIII.43/44(2).

41. Id. Alt. $53 \mathrm{~mm}$. Cabeça em forma de diamante. Haste de secção circular. CUC.86.Tanq.W.T9(3).

42. Id. Alt. $42 \mathrm{~mm}$. Cabeça em forma de cebola independente da haste ; esta é de secção circular e volumosa. CUC.81.XIII.48(6).

43. Lâmina para barba. Ferro. Compr. $79 \mathrm{~mm}$. Conserva um dos braços com lâmina larga, de feição triangular. CUC.84.XX.49(3).

44. Pinça. Bronze. Compr. $85 \mathrm{~mm}$. Dois braços paralelos e estreitos, unidos por meio de um anel oval e apertado. Extremos espalmados e dobrados em ângulo agudo. CUC.79.XVII.29(3).

45. Id. Compr. $84 \mathrm{~mm}$. Braços espessos, de secção rectangular e de pontas direitas, unidos por uma folha dobrada, de feição trapezoidal. CUC. 82. XXIV. 28(5). 
46. Sonda (cyathiscomela). Bronze. Compr. $155 \mathrm{~mm}$. Haste de secção circular com um dos extremos terminado em bolbo e o outro numa colherinha ovalada. CUC.86.S2(3).

47. Id. (specillum). Bronze. Compr. $155 \mathrm{~mm}$. Haste de secção circular com um dos extremos terminado numa lâmina lanceolada. CUC. 84.XVA.7(2).

48. Id. Compr. $109 \mathrm{~mm}$. Semelhante ao anterior, mas de proporções mais reduzidas. CUC.82.XX.3(4).

49. Id. Compr. $58 \mathrm{~mm}$. Semelhante aos dois exemplares anteriores. CUC.82.XX.2(3).

\section{Equipamento militar e peças de arnês}

Nesta rubrica incluímos peças metálicas que poderão ter servido tanto em actividades militares como civis. Referimo-nos às armas de impacto no combate corpo a corpo \{hasta) e às armas de arremesso \{pilum) que, fazendo parte do equipamento militar, eram também usadas na caça ou no desporto equestre (n.os 50-57); às fivelas (n. os 61-68), elementos de corroías (n. ${ }^{\circ}$ 69), e botões (n. ${ }^{\circ}$ 70) usados na indumentária civil e no fardamento militar; por fim, às peças de arnês destinadas ao equipamento de animais (n. ${ }^{\circ}$ s 65-67, 71-72).

Os vocábulos latinos hasta e pilum não eram unívocos $\left({ }^{27}\right)$. A infantaria usava como arma de choque o pilum pesado, enquanto que a cavalaria era equipada com uma arma de arremesso mais ligeira \{pilum spiculum). A lança de haste (hasta) era usada na defesa corpo a corpo, tanto pela infantaria corno pela cavalaria; a sua diferença residia no tamanho e no peso $\left({ }^{28}\right)$. A hasta velitaris $\left({ }^{29}\right)$ ou dardo ligeiro de um veles era semelhante à lança de haste (hasta), embora mais leve e mais pequena. 0 pilum catapultuarium era outra arma de arremesso usada pela artilharia romana, arma

(27) Cf. Fouilles de Conimbriga, VII, p. 85-86.

i28) Cf. Lave D an (Pierre), Dictionnaire Illustré de la Mythologie et des Antiquités Grecques et Romaines, Paris, 1931, p. 572-573.

(29) Cf. Rich (Anthony), Dictionnaire des Antiquités Romaines et Grecques, Paris, 1861, p. 698 (velites); Connolly (Peter), O exército romano, Londres, 1975, p. 19. 
cujas ponteiras de seta \{́pilum) eram lançadas de uma catapulta $\left(^{30}\right)$. Reconhecemos, apesar da ambiguidade terminológica de hasta e pilum, na ailla romana de S. Cucufate, a lança de haste (n. ${ }^{\circ} 50$ ), as pontas de dardo (n. ${ }^{\circ}$ 51-52) e várias modalidades de pilum (n. ${ }^{\circ}$ 53-57).

Conhecemos para os n.os 50-57 vários modelos achados em Heddernheim ( $\left.{ }^{31}\right)$, Straubing-Sorviodurum( $\left.{ }^{32}\right)$, Fishbourne $\left({ }^{33}\right)$ e em Conimbriga ( $\left.{ }^{34}\right)$ datáveis entre os sécs. I-III d. C. O n. ${ }^{\circ} 53$ encontra paralelo em Conimbriga ( ${ }^{35}$ ) ; poderia ter sido um pilum pesado com a ponteira curta e em rebarba. Este modelo foi adoptado nos meados do séc. i d. C., no tempo de Domiciano( $\left.{ }^{36}\right)$. Os n. ${ }^{\text {os }} 54-57$ aproximam-se, por sua vez, do tipo de pilum catapultuarium.

$\mathrm{O}$ n. ${ }^{\circ} 58$ é uma virola de pilum, a qual servia para manter fixa ao chão a ponta da haste da arma. $\mathrm{O}$ n. ${ }^{\circ} 59$ é um terminal da espada, sugerindo um exemplar de Krefeld-Gellep, pertencente a uma sepultura de incineração datada entre 400/525 d. C.(37). $\mathrm{O}$ n. ${ }^{\circ} 60$ corresponde provavelmente a uma bainha de adaga.

${ }^{(30)}$ Cf. Fouilles de Conimbriga, VII, p. 88; Connolly (P.), op. cit., p. 66-67.

(31) Cf. Fischer (Ulbert), Grabungen im römischen Steinkastell von Heddernheim 1957-1959, Frankfurt, 1973, p. 112-113, fig. 30, n. ${ }^{\circ} 6-7$ (lança e pilum catapultuarium — séc. ii d.C.; p. 122, n. ${ }^{\circ} 9$ (lança-séc. ii-iii d.C.); p. 124, fig. 36, n. ${ }^{\circ}$ 9-11 [pilum catapultuarium; pilum spiculum e dardo

— séc. II-III C.C.); p. 127, fig. 38, n. ${ }^{\circ} 9-10$ (dardo e pilum catapultuarium - séc. in d.C.).

(32) Cf. Walke (Norbert), Das Römische DonauKastell Straubing-Sorviodurum, Berlim, 1965, p. 23, 123, 153, Est. 107, n. ${ }^{\circ} 8-9$ (lanças) ; Est. 108, n. ${ }^{\circ}$ 6-8 (dardos) e n. ${ }^{\circ}$ 14-27 (pilum catapultuarium). Estes objectos são datados entre os sécs. II-III d.C.

(33) Cf. Cunliffe (B.), op. cit., p. 134, fig. 60, n. ${ }^{\circ} 47$ (lança, datada entre 100-280 d.C.) e n. ${ }^{\circ} 49$ (pilum catapultuarium, datado entre 100-280 d.C.).

(M) Cf. Fouilles de Conimbriga, VII, p. 86, Est. XVII, n. ${ }^{\circ}$ 1-2 (são duas pontas de lança, a primeira das quais achada nas fundações do forum augustano) e o n. ${ }^{\circ} 4$ (dardo proveniente da camada flaviana); p. 88, Est. XVIII, n. ${ }^{\circ}$ 18-19 [pilum catapultuarium, achados em níveis correspondentes à construção do forum flaviano).

(35) Cf. id., ibidem, p. 88, Est. XVIII, n. ${ }^{\circ} 17$.

(36) Cf. Connolly P(.), op. cit., p. 51.

(37) Cf. Pir ling (Renate), Das Römische-Fränkische Gräberfeld von Krefeld-Gellep, Berlim, 1966 (1), p. 22; (2), p. 20, Est. 10, n. ${ }^{\circ}$ 43, la-lf. 
As fivelas n.os 61 a 66 eram usadas tanto no fardamento militar como no equipamento de arnés. $\mathrm{O}$ n. ${ }^{\circ} 61$ é uma fivela de cinturão usual nos finais do séc. I-II d. C. Provam-no os exemplares de Gonimbriga ( $\left.{ }^{38}\right)$, Richborough ( ${ }^{39}$ ), Aislingen e Burghofe $\left({ }^{40}\right)$. Os n. ${ }^{\text {os }}$ 62-64 cabem num tipo que aparece associado ao fardamento militar da época romana tardia. Conhecemos vários modelos em Krefeld-Gellep $\left({ }^{41}\right)$, em Fishbourne $\left({ }^{42}\right)$ e em Straubing-Sorviodurum( $\left.{ }^{43}\right)$, datáveis entre os sécs. $\mathrm{m}$ e o v d. C. ; as outras fivelas (n. ${ }^{\text {os }}$ 65-66) pertencem ao correame usado no equipamento de arnês. Estes objectos situam-se no Baixo Império ou já em época bárbara $\left({ }^{44}\right)$.

O n. ${ }^{\circ} 67$ é um elemento de correia com pendente a decorá-lo. Esta forma sugere os pingentes das couraças comuns em sítios romanos, nomeadamente em Rheingönheim, datáveis dos sécs. I-II d. C. $\left({ }^{45}\right)$. $\mathrm{O} \mathrm{n.}{ }^{\circ} 68$ é uma placa de cinturão de técnica semelhante a dois exemplares de Richborough $\left({ }^{46}\right)$. A presilha de correia n. ${ }^{\circ} 69$ era uma espécie de gancho que unia duas partes do tecido ou da pele. Esta forma, correspondente ao tipo IX de Wild, ocorre entre os sécs. $n$ e m d. G. $\left({ }^{47}\right)$.

${ }^{(38)}$ Cf. Fouilles de Conimbriga, VII, p. 96-97, Est. XX, n. ${ }^{\circ} 67-68$.

(39) Cf. Cunliffe (B. W.), Fifth Report on the Excavations of the Roman Fort at Richboroug, Kent, Oxford, 1968, p. 93-94, Est. XXV, n. ${ }^{\circ}$ 97-98. $\mathrm{O}$ autor data-os de $80-120$ d.C.

$\left({ }^{40}\right)$ Cf. Ulbert (Gunter), Die Römischen Donau-Kastelle Aislingen und Rurghofe, Berlini, 1959, p. 106, Est. 61, n. ${ }^{\circ} 28$.

(41) Cf. Pirling (R.), op. cit., p. 192-194, fig. 21. O autor data-os do séc. v d.C.

(42) Cf. Cunliffe (B.), op. cit. (v. nota 9), p. 110, fig. 44, n. ${ }^{\circ}$ 87-88. O autor data-os post 280 d.C.

(43) Cf. Walke (N.), op. cit., p. 52, Est. 97, n. ${ }^{\circ}$ 13. O autor data-os do séc. iii-iv d.C.

$\left.{ }^{44}\right)$ Cf. Fouilles de Conimbriga, VII, p. 97 ; B Rown (P.D.C.), The ironwork in Excavations at Shakenoak Farm, near Wilcote, Oxfordshire, Oxford, 1972. p. 86,117 , fig. 43, n. $^{\circ} 199$.

$\left({ }^{45}\right)$ Cf. Ulbert (Gunter), Das frührömische Kastell Rheingönheim, Berlim, 1969, p. 45-46, Est. 34, n. ${ }^{\circ} 45-52$.

$\left({ }^{46}\right)$ Cf. Bushe-Fox (J. P.), Fourth Report on the Excavations of the Roman Fort at Richboroug, Kent, Oxford, 1949, p. 148, Est. LIV, n. ${ }^{\circ} 225$ e 228 , $\mathrm{O}$ autor data-os dos sécs. II-III d.C.

${ }^{(47)}$ Cf. Fouilles de Conimbriga, VII, p. 99, Est. XXI, n. ${ }^{\circ} 88$.

Conimbriga, 26 (1987), 133-165 
$\mathrm{O}$ n. ${ }^{\circ} 70$ pertence à categoría de botões que tanto fixavam a extremidade de cintos e de cinturões do fardamento militar, como prendiam as tiras de cabedal do equipamento de arnés. Surgem em vários sítios romanos durante os sécs. I-Iv d. C., destacando-se pela variedade de talhe e de diámetro que ostentavam $\left({ }^{48}\right)$. O n. ${ }^{\circ} 70$ aproxima-se de dois exemplares de Heddernheim datáveis dos sécs. i-ii d. C. $\left.{ }^{49}\right)$.

A corrente $n .^{\circ} 71$ e o eixo $n .^{\circ} 72$, em ferro, tinham diversas aplicações utilitárias, aparecendo estes objectos associados quer ao mobiliário, quer ao equipamento de atrelagem e de arnês $\left({ }^{50}\right)$.

50. Ponta de lança. Ferro. Gompr. $150 \mathrm{~mm}$. Lâmina larga em forma de folha de loureiro com encabamento em alvado. CUC.84.X.8(2).

51. Ponta de dardo. Ferro. Compr. $142 \mathrm{~mm}$. Lâmina lanceolada, de secção oval com encabamento em alvado. CUC.84.XIV.46(3).

52. Id. Compr. actual: $178 \mathrm{~mm}$. Lâmina mais estreita que a anterior e ponta aguçada. Encabamento em alvado. CUC.81.XIII.8(4).

53. Pilum. Ferro. Compr. $290 \mathrm{~mm}$. Cabeça romboidal bastante curta e haste maciça de secção quadrangular. CUC.84.XV.A1(4).

54. Id. Compr. $128 \mathrm{~mm}$. Cabeça em forma de pirâmide quadrangular, alongada. Encabamento em alvado. CUC.83.XV.1 Banq. Sul(2).

55. Id. Comp. $145 \mathrm{~mm}$. Semelhante ao anterior, mas de maiores proporções. CUC.83. XV. 36(3).

56. Id. Compr. $92 \mathrm{~mm}$. Ponta de secção rectangular, adelgaçando-se para o topo. Encabamento em alvado. CUC.79.VIII.8(3).

57. Id. Compr. $74 \mathrm{~mm}$. Cabeça em forma de cone prismático e alvado ligeiramente aberto. CUC.80.VIII.7.lado sul(1).

58. Virola de pilum. Ferro. Compr. $55 \mathrm{~mm}$. Cone aberto cavado quase até à ponta. CUC.83.XIV.23/24 Banq. Sul(2).

(48) Cf. id., ibidem, p. 106.

(49) Cf. Fischer (Lurich), op. cit., p. 92 e 94, fig. 19, n. ${ }^{\circ} 11$ e 16.

$\mathrm{O}$ autor data-os do período I-II (séc. I-II d.C.).

${ }^{(50}$ Cf. Walke (N.), op. cit., p. 61,162 , Est. 131, n. ${ }^{\circ} 17-18$ e 20 ; F ISCHER (Ulbert), op. cit., p. 42, fig. 42, n. $^{\circ} 7 . \mathrm{O}$ autor data a corrente do séc. III d.C. 
59. Terminal de bainha. Ferro. Alt. $30 \mathrm{~mm}$. Larg. $27 \mathrm{~mm}$. Ponta triangular com base côncava. CUG.81.XIII.6/7(2).

60. Bainha de adaga. Ferro. Dim.: 50x11 mm. Aro rectangular de lados menores cóncavos. CUC.84.X.17(S/E).

61. Fivela. Bronze. Compr. total: $61 \mathrm{~mm}$. Aro rectangular de lados côncavos, cujos cantos anteriores terminam num botão. Fusilhão e placa encaixam num eixo transversal que une os cantos posteriores da fivela. Placa com dois cravos. CUG.84.T9 oeste(4).

62. Id. Bronze. Dim. : $\mathbf{3 6 X 3 0} \mathrm{mm}$. Aro em forma de $\mathrm{D}$, com a parte central bastante dilatada e o travessão rectilíneo. A face anterior é decorada por dois finos sulcos interrompidos a meio por um chanfro rebaixado. CUC.80.S1(E).

63. Id. Dim.: $42 \times 29 \mathrm{~mm}$. Aro oval com a parte média espalmada e dilatada; extremos chanfrados e travessão rectilíneo. A face anterior do aro é decorada com incisões muito profundas. CUG.81. XIII.1/2(2).

64. Id. Dim.: $32 \times 30 \mathrm{~mm}$. Aro rectangular com os lados constrictos, formando volutas simples e a parte média arqueada com quatro molduras verticais. Travessão rectilíneo e fusilhão em fita. CUG. 81.VI 11.22(2).

65. Id. Ferro. Diâm. 55 mm. Aro quadrangular, de secção rectangular. Fusilhão com um dos extremos em fita. CUC.80.N 11 (D) (2).

66. Id. Dim.: $60 \times 40 \mathrm{~mm}$. Aro em forma de $\mathrm{D}$, de secção rectangular. Conserva arranque de fusilhão. CUG.80.S 15C(7).

67. Elemento de couraça. Bronze. Compr. $150 \mathrm{~mm}$. Placa rectangular de secção troncocònica ligada a um pingente por meio de uma corrente. Pingente em forma de folha triangular. CUC.86, tanque W,T9(3).

68. Placa de cinturão. Bronze dourado. Compr. $29 \mathrm{~mm}$. Chapa rectangular, fina, com decoração geométrica aberta a cinzel CUC.79.8(2A).

69. Presilha de correia. Bronze. Compr. $34 \mathrm{~mm}$. Pé com anel oval e travessão rectangular. GUC.83.XV.2A(2).

70. Botão. Bronze. Alt. $7 \mathrm{~mm}$. Cabeça: 22x25 mm. Cabeça em forma de cúpula com arranque do pedúnculo. CUC.84.X.9.Banq. Este(1). 
71. Corrente. Ferro. Compr. $128 \mathrm{~mm}$. Formada por 3 elos rectangulares, unidos entre si, dois dos quais de lados maiores constrictos. CUC.82.XX.2(2).

72. Eixo. Ferro. Compr. $76 \mathrm{~mm}$. De forma e seç̧ão circulares, apresenta os extremos coroados por um largo botão cónico. CUC.84.1/2 Y 28(1).

\section{Vária}

Nesta rubrica englobamos objectos de usos muito variados, feitos de metal (n. ${ }^{\text {ss }} 73$ a 109, 113-138), osso (n. $\left.{ }^{\circ} 110\right)$ e cerâmica (n. ${ }^{\text {os }}$ 111-112).

Os utensílios de cozinha são pouco numerosos (n. ${ }^{\text {os }} 73-85$ ). $\mathrm{O}$ n. ${ }^{\circ} 73$ corresponde a uma escudela, presumivelmente sem pé. Esta forma situa-se entre os sécs. i e $\mathrm{m}$ d.C. (51). Conhecemos um exemplar semelhante em Straubing-Sorviodurum, tipo 82 de Eggers, do séc. $\mathrm{m}$ d. C. ${ }^{52}$ ). $\mathrm{O}$ n. ${ }^{\circ} 74$ é uma colherinha de um passador, em ferro. Os n. ${ }^{\circ}$ 75-77 são pegas, respectivamente, de simpulum, de caçarola e de pátera. A pega n. ${ }^{\circ} 75$ é estreita e remata numa pequena concha perfurada. Pertence a um simpulum. Esta forma aparece em vários sítios romanos, nomeadamente em Aislingen e Burghofe ${ }^{(53}$ ) e em Rheingönheim $\left({ }^{M}\right)$, no séc. i d. C. A decoração da pega $n .^{\circ} 76$ sugere uma sobrevivência temática de motivos do período pré-romano. Julgamos, no entanto, que este exemplar pode situar-se no séc. i d. C. ( $\left.{ }^{55}\right)$.

$\mathrm{O}$ n. ${ }^{\circ} 77$, pela decoração obtida por meio de moldagem, constitui um modelo corrente no séc. i d. C. $\left.{ }^{56}\right)$, com exemplares em Aislingen e Burghofe ${ }^{(57)}$ e em Rheingönheim ( $\left.{ }^{58}\right)$. O n. ${ }^{\circ} 78$ é uma

(51) Cf. Boestead (Maria H. P. Pen), The bronze vessels, Nijmegen, 1956, p. 33, Est. IV, n. ${ }^{\circ} 90$.

(52) Cf. WALKe (N.), op. cit., p. 63, Est. 115, n. ${ }^{\circ} 1$.

(53) Cf. Ulbert (Gunter), op. cit., (Y. nota 40), p. 21, Est. 23, n. ${ }^{\circ} 3-4$.

(54) Cf. Ulbert (G.), op. cit. (V. nota 45), p. 47, Est. 37, n. ${ }^{\circ} 4$.

(55) Cf. Boestead (Maria H. P. Pen), op. cit., p. 34, Est. IY, n. ${ }^{\circ} 97$.

(56) Cf. id., ibidem, p. 10-11, Est. II, n. ${ }^{\circ}$ 25-29.

(57) Cf. Ulbert (G.), op. cit. (Y. nota 39), p. 62, Est. 23, n. ${ }^{\circ} 10$.

(58) Cf. Ulbert (G.), op. cit. (V. nota 45), p. 48, Est. 37, n. ${ }^{\circ}$ 12-14. 
tampa de bronze que poderia ter servido como cobertura a urna caixa de jóias, de dados ou de farmácia. Não achamos para este exemplar nenhum paralelo. O n. 79 é um pé de vaso com vestígios de um rebite a meio.

Os n. ${ }^{\text {ss }} 80-85$ são facas (cultii) usadas na cozinha, no talho e/ou em cerimónias religiosas (n. ${ }^{\circ}$ 85). Os n. ${ }^{\text {os }}$ 80-82 têm uma lâmina estreita, enquanto os outros três (n. os 83-85) apresentam uma lâmina larga, em cutelo. $\mathrm{O}$ n. ${ }^{\circ} 85$ é um cutelo mais apropriado para talhar carne; as facas de lâmina estreita com ressalto junto ao dorso tornam-se abundantes nos finais do Império Romano. Comprovam-no os modelos de Conimbriga ( ${ }^{59}$ ), Verulamium $\left({ }^{60}\right)$ e Fishbourne ( $\left.{ }^{61}\right)$ que aparecem em níveis tardios. Conhecemos alguns exemplares de Verulamium ( ${ }^{62}$ ), Heddernheim $\left({ }^{63}\right)$ e Straubing-Sorviodurum ( ${ }^{64}$ ) achados em vários níveis do período romano.

Os n. ${ }^{\text {os }} 86-88$ são espelhos de fechadura; os dois primeiros têm uma abertura rectangular pouco vulgar. $\mathrm{O}$ n. ${ }^{\circ} 88$ conserva os dois cravos de fixação e vestígios da abertura para as chaves. A sua decoração faz lembrar uma placa idêntica de Conimbriga ${ }^{(65)}$. Conhecemos vários exemplares achados em Conimbriga ( ${ }^{66}$ ), Straubing-Sorviodurum ( $\left.{ }^{67}\right)$ e Cambodunum ( $\left.{ }^{68}\right)$ no séc. i d. C.

O n. ${ }^{\circ} 89$ é uma folha recortada que serviria de aplicação a

${ }^{(59)}$ Cf. Fouilles de Conimbriga, VII, p. 161-162, Est. XLI, n. ${ }^{\circ} 69-72$ e Est. XLII, n. ${ }^{\circ} 72-82$.

${ }^{(60}$ ) Cf. Frene (S.), op. cit., (V. nota 26), p. 195, fig. 73, 162. O autor data-o entre 280-315 d.C.

(61) Cf. Cunliffe (B.), op. cit., (V. nota 9), p. 134, fig. 60, n. ${ }^{\circ}$ 46. Data este exemplar do $3 .^{\circ}$ período, ou seja, de 100 a 280 d.C.

(62) Cf. Frere (S.), op, cit., (V. nota 26), p. 40, fig. 65. O autor data-o de 280-315 d.C.

(63) Cf. Fischer (U1.), op. cit., (V. nota 31), p. 134, fig. 43, n. 9. $\mathrm{O}$ autor data-o do período I-II, ou seja, do séc. I-II d.C.

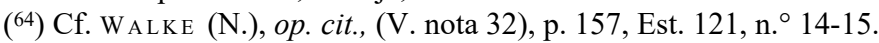

$\left.{ }^{65}\right)$ Cf. Fouilles de Conimbriga, VII, p. 167, Est. XLV, n. ${ }^{\circ} 128$.

(66) Cf. id., ibidem, p. 167, Est. XLV, n. ${ }^{\circ} 125$.

(67) Cf. Walke (N.), op. cit., p. 59 e 159, Est. 124, n. ${ }^{\circ} 3$.

(68) Cf. Kramer (Werner), Cambodunumforschungen 1953-1, Kallmunz, 1957, p. 68, Est. 19, n. ${ }^{\circ} 41$. O autor data-o do período ï, ou seja, de Augusto a Tibério. 
uma peça de mobiliário ( ${ }^{69}$ ). A tranca e o aloquete ou cadeado constituíam a segurança das portas romanas. A cada um dos sistemas correspondia um dado tipo de chaves $\left({ }^{70}\right)$ : a chave de palhetão ou chave para tranca (n. ${ }^{\circ}$ 90-91); a chave em L ou chave para aloquete ( $\mathrm{n} .{ }^{\circ}$ 92); a chave para tranqueta (n.os 93-94) e a chave rotativa (n. ${ }^{\circ}$ 95-97). A primeira, formada por vários dentes, funcionava no sentido vertical ou lateral; a chave de aloquete funcionava nos dois sentidos, vertical daterai, tornando-se numa modalidade de chave de tranca $\left({ }^{71}\right)$; a chave para tranqueta obedecia ao mesmo sistema da chave de tranca; a chave rotativa provocava um movimento de rotação completo como nos modelos modernos.

A chave de tranca e a chave para aloquete foram usadas em Pompeios até 79 d. C.(72). Conhecemos para os n.os 90-94 vários paralelos em Conimbriga (73), Verulamium (74), Aislingen e Burghöfe ( $\left.{ }^{75}\right)$, em Cambodunum $\left({ }^{76}\right)$, Straubing $\left({ }^{77}\right)$, em Richboroug $\left({ }^{78}\right)$, em Heddernheim $\left({ }^{79}\right)$ e Fishbourne $\left({ }^{80}\right)$, datáveis entre os sécs. i d. C. e IV d. C.

(69) Cf. Walke (N.), op. cit., p. 162, Est. 133, n. ${ }^{\circ} 31$. O autor data-o do séc. i d.C.

${ }^{70}$ Cf. London in Roman Times (London Museum Catalogues, $n .{ }^{\circ} 3$ ), Londres, 1946, p. 70.

(71) Cf. id., ibidem, p. 70.

(62) Cf. id., ibidem, p. 72.

(73) Cf. Fouilles de Conimbriga, VII, p. 172, Est. XLV, n. ${ }^{\circ}$ 149-159 (o n. ${ }^{\circ} 149$ foi achado num nível correspondente à construção do forum flaviano).

(74) Cf. Frere (S.), op. cit., p. 182, fìg. 68, n. $^{\circ} 75$ (270-275 d.C.), n. ${ }^{\circ} 76$ (80 d.C.), n. ${ }^{\circ} 77$ (Séc. iv d.C.) e p. 183, fìg. 68, n.o 78 (140-150 d.C.).

(75) Cf. Ulbert (G.), op. cit., (V. nota 40), p. 103, Est. 53, n. ${ }^{\circ} 14$; p. 107 , Est. 67 , n. ${ }^{\circ} 12-15$ (Séc. I-II d.C.).

${ }^{(76)}$ Cf. Kramer (W.), op. cit., p.68, Est. 19, n. ${ }^{\circ} 33-38$.

(77) Cf. Walker (N.), op. cit., p. 59 e 158, Est. 122, n.o 4-7, 10-17 e Est. 123, n. $^{\circ} 1-12$ (Séc. I-III d.C.).

(78) Cf. Cunliffe (B. W.), op. cit., (V. nota 39), p. 33 e 104, Est. XLVI, n. ${ }^{\circ} 201$ (pré-flaviano) e n. ${ }^{\circ} 203$ (Séc. iv d.C.).

(79) Cf. Fischer (U1.), op. cit., (V. nota 31), p. 117, fìg. 34, n. ${ }^{\circ} 2$ (161-176 d.C.); p. 134, fìg. $44, n{ }^{\circ} 1,3$ e 5 (Séc. I-II d.C.) e n. ${ }^{\circ} 4$ (Séc. i-1.a metade do II d.C.).

(80) Cf. Cunliffe (B.), op. cit., (V. nota 9), p. 131, fìg. 58, n. ${ }^{\circ} 27$ (75/80-280 d.C.); . $^{\circ}$ 28-31 (100-280 d.C.). 
A chave rotativa aparece igualmente em Conimbriga ( $\left.{ }^{81}\right)$, Fishbourne ( ${ }^{82}$ ) e Straubing-Sorviodurum ( ${ }^{83}$ ) entre o séc. i e o séc. ni d. C.

O mecanismo dos cadeados n.os $98-99$ é semelhante ao dos modelos de Verulamium ( ${ }^{84}$ ) e de Finsbury Circus ( ${ }^{85}$ ), situados entre os sécs. $\mathrm{n}$ e iv d. C. O n. ${ }^{\circ} 98$ é de forma oval, podendo ser já um modelo muito mais tardio.

Os n. ${ }^{\text {ss }} 100-101$ são duas peças cruciformes que eram usadas na intersecção de barras transversais e verticais de gradeamentos de janelas e portas. Não encontramos para estas peças nenhum paralelo.

Os instrumentos de escrita [styli) limitam-se a dois exemplares de ferro (n.os 102-103). Escrevia-se com eles em tabuinhas de cera; a extremidade ponteaguda traçava e marcava os caracteres; a outra extremidade espatulada servia para apagar ou corrigir os caracteres errados. São numerosos os exemplares achados em vários sítios romanos.

Os n. ${ }^{\text {s }}$ 104-107 pertencem ao grupo de instrumentos para pesar e medir mercadoria. O n. ${ }^{\circ} 104$ é uma balança greco-romana (libra ou talentum), marcada num dos braços por 12 golpes equidistantes. Cada golpe corresponde a uma semisestula (1/12 da onça), ou seja, a 2,245 grs., ou 2,27 grs. ( ${ }^{86}$ ). O valor da onça é de 26,938 grs. ou 27,29 grs.

$\mathrm{O}$ n. ${ }^{\circ} 105$ é um prato que, pelas suas dimensões reduzidas, deveria ter pertencido a uma balança idêntica à do $\mathrm{n}^{\circ} 104$. Conimbriga fornece-nos alguns bons exemplares de pequenas balan-

(81) Cf. Fouilles de Conimbriga, VII, p. 173, Est. XLVIII, n. ${ }^{\circ} 173$ (foi achado num nível de revolvimento).

(82) Cf. Cunliffe (B.), op. cit., (V. nota 9), p. 131, fig. 58, n. ${ }^{\circ} 32$ (100-280 d.C.).

(83) Cf. Walke (N.), op. cit., p. 59 e 158, Est. 123, n. ${ }^{\circ} 16$ e 23 (Séc. md.C.).

H Cf. Frere (S.), op. cit., (V. nota 26), p. 181, fig. 67, n. $<>\quad 66-67$ (155-160 d.C.) e n. ${ }^{\circ} 68$ (280-315 d.C.).

(85) Cf. London in Roman Times, p. $\quad 72-73$, fig. 17 (post. 100 d.C.).

(86) Cf. Fouilles de Conimbriga, VII, p. 177-178; Cf. Ponte (Salete da), Balanças e Pesos de Conimbriga, «Conimbriga», 18, 1979, p. 121-132 (p. 124). 
ças greco-romanas e respectivos pratinhos $\left({ }^{87}\right)$. O valor real dos dois pesos prismáticos de chumbo (n. $\left.{ }^{\circ s} 106-107\right)$ fica aquém do seu valor nominal; o n. ${ }^{\circ} 106$, correspondente à uncia (26,938 grs. ou 27,28 grs.), pesa 26,94 grs.; o n. ${ }^{\circ} 107$ pesa 286,10 grs., não atingindo, assim, o valor nominal do «deunx», ou seja, onze onças $\left.{ }^{88}\right)$.

Os pesos apresentam muito raramente correspondencia entre o valor nominal e o real. O desgaste provocado pelo uso e pelo enterramento concorrem necessariamente para a diferença do valor ponderal $\left({ }^{89}\right)$.

Os objectos n. ${ }^{\text {s }} 108-109$ serviam para espevitar e extinguir a chama das lamparinas de azeite [lucernae). Ocorrem com muita frequência em muitos sítios romanos $\left({ }^{90}\right)$. A representação miniatural de figuras em metal, osso e cerâmica é, por assim dizer, o reflexo da vida espiritual romana. As figuras representavam, como amuletos, o poder propiciatório, mágico e religioso; como brinquedos e adornos pessoais, copiavam figuras da vida real, recreando ou teatralizando cenas do quotidiano.

$\mathrm{O} \mathrm{n} .^{\circ} 110$ representa uma figura feminina estilizada, cujas incisões marcam os seus traços fisionómicos e anatómicos. A perfuração junto aos ombros serviria para a passagem de um fio $\left({ }^{91}\right)$ e não de uma cavilha para o encaixe dos braços articulados ( ${ }^{92}$ ). Este tipo é comum nos sítios romanos peninsulares. Assumir-se-á como amuleto encomendando as jovens noivas à protecção dos deuses Lares e Penates ? ${ }^{93}$ ). É uma questão ainda em aberto. Os n. ${ }^{\text {ss }} 111-112$ são duas peças cerâmicas pertencentes a figurinhas humanas: uma, correspondente a uma máscara feminina (n. ${ }^{\circ} 111$ ) e outra, a um braço direito inflectido com a mão semi-cerrada.

(87) Cf. Fouilles de Conimbriga, VII, p. 176-177, Est. XLVIII, n. ${ }^{\circ} 184-185$ e 187 a-b; PONTE, art. cit., (V. nota 86), p. 124-126, Est. I, n. ${ }^{\circ}$ 3-7 e n. ${ }^{\circ} 13-14$.

(88) O valor nominal do deunx é de 296,381 grs. ou de 300,16 grs.

(89) Cf. PONTE (S.), art. cit., (V. nota 86), p. 127-129.

$\left({ }^{90}\right)$ Cf. Fouilles de Conimbriga, VII, p. 189, Est. LUI, n. ${ }^{\circ}$ 302-303.

(91) Cf. id., ibidem, p. 192, Est. LUI, n. $<>315$.

(92) Cf. Lafaye (Georges), Pupa, in Dictionnaire des Antiquités Grecques et Romaines, Paris, 1907, p. 768-769.

(93) Cf. id., ibidem, p. 768. 
Estas figurinhas fazem parte do universo religioso da cultura romana.

Os n. ${ }^{\text {os }} 113-114$ são instrumentos sonoros usados pelos Romanos para protegerem a casa e afugentarem os espíritos. O n. ${ }^{\circ} 114$ é um guizo de prata que deveria ter pertencido a um crepitaculum (guizo). Este instrumento musical era usado como objecto cultual ( $\left.{ }^{94}\right)$. Conhecemos um exemplar achado em Pompeios $\left({ }^{95}\right)$. $\mathrm{O}$ guizo de $\mathrm{S}$. Cucufate foi recolhido no templo, o que permite associá-lo a cerimónias de cariz religioso. Conhecemos vários paralelos achados em Verulamium ( ${ }^{96}$ ), Fishbourne ${ }^{97}$ ), Aislingen e Burghofe ( $\left(98^{*}\right)$ e em Rheingönheim (").

Os n.os 115-134 reúnem uma diversidade de pregos usados na construção de edifícios.

Os n.os $118,120-121,127$ e 134 fornecem-nos, pela haste dobrada em $\mathrm{L}$ ou em $\mathrm{U}$, a espessura da madeira que teriam de fixar.

Os n. ${ }^{\text {os }} 135-138$ são ganchos de suspensão com diversas utilidades. Encontramo-los abundantemente em Conimbriga $\left({ }^{100}\right)$, Richborough (101), Heddernheim (102) e Straubing-Sorviodurum (103). O exemplar de Richborough aparece associado a um peso de bronze; outros ganchos similares são, porém, usados para suspender lucernae.

(94) Cf. Lavedan (P.), op. cit., p. 192, fig. 207 (carrilou).

(95) Cf. Rich (A.), op. cit., p. 202 (crepitaculum).

(96) Cf. Frere (S.), op. cit., p. 126, fig. 37, n. ${ }^{\circ} 93$. O autor data-o de 310-315 d.C.

(97) Cf. Cunliffe (B.), op. cit., (V. nota 9), p. 112, fig. 46, n. ${ }^{\circ} 107$. $\mathrm{O}$ autor data-o entre 100-280 d.C.

${ }^{98}$ ) Cf. Cunliffe (G.), op. cit., (V. nota 40), p. 75 e 106, Est. 65, n. ${ }^{\circ} 6$.

(") Cf. Ulbert (G.), op. cit., (V. nota 45), p. 49, Est. 40, n. ${ }^{\circ} 7$.

$\left(1^{\circ}\right)$ Cf. Fouilles de Conimbriga, VII, p. 186, Est. LI-LII, p. ${ }^{\circ} 256-264$ (semelhantes aos n. $\left.{ }^{\text {os }} 143-144\right)$.

(101) Cf. Bushe-Fox (J. P.), Third Report on the excavations of the Roman Fort at Richborough, Kent, Oxford, 1932, p. 82-83, Est. XIV, n. ${ }^{\text {os }} 44$ a 47 (semelhante ao n. ${ }^{\circ} 145$ ).

(102) Cf. Fischer (UL), op. cit., (V. nota 31), p. 109, fig. 27, n. ${ }^{\circ} 6$ (semelhante ao . $\left.^{\circ} 145\right)$.

(103) Cf. Walke (N.), op. cit., (V. nota 32), p. 159, Est. 124, n. ${ }^{\circ} 16$ (semelhante ao n. ${ }^{\circ} 145$ ). 
73. Escudela. Bronze. Diâm. $120 \mathrm{~mm}$. Conserva a aba voltada para o exterior e parte da parede do vaso. CUC.83.VIII.27(3).

74. Passador. Ferro. Dim.: $28 X 25 \mathrm{~mm}$. Placa oval, côncava, crivada de pequenos orifícios circulares. CUC.79.XV 1(1).

75. Simpulum. Bronze. Compr. $77 \mathrm{~mm}$. Haste e secção rectangugulares com um dos extremos coroados por uma concha de pequenos orifícios. CUC.83.IVA 41/42(1).

76. Cabo de caçarola. Bronze. Compr. $235 \mathrm{~mm}$. Haste e secção rectangulares com a orla decorada por um friso contínuo de SS e por um largo círculo impresso. A face posterior conserva vestígios de solda. CUC.80.III.16(2).

77. Cabo de pátera. Bronze. Compr. $80 \mathrm{~mm}$. Terminal de haste em forma de disco decorado por um cordão em relevo circunscrito e um outro que acompanha a orla do cabo. CUC.83.XV.26(3).

78. Tampa. Bronze. Diâm. $35 \mathrm{~mm}$. Alt. $7 \mathrm{~mm}$. Disco oco com orla vertical. CUC.84.IX.48(2).

79. Pé de vaso. Bronze. Compr. $46 \mathrm{~mm}$. Peça em forma de peita alongada, com os extremos adelgaçados. CUC.84.X.27 Banq. $\operatorname{Sul}(\mathrm{S} / \mathrm{E})$.

80. Faca. Ferro. Compr. $115 \mathrm{~mm}$. Lâmina estreita e rectangular com ressalto entre o dorso rectilínio e a lâmina. Espigão longo e estreito. CUC.79.S1(S/E).

81. Id. Compr. $160 \mathrm{~mm}$. Semelhante à anterior, mas de maiores proporções. CUC.82.XXIV.28(5).

82. Id. Compr. $140 \mathrm{~mm}$. Semelhante à anterior, mas de gume concavo. CUC.81.V.19(2).

83. Cutelo. Ferro. Compr. $172 \mathrm{~mm}$. Lâmina larga, triangular com dorso rectilíneo. Espigão de secção rectangular. CUC.83.IVA.2/3 (1).

84. Id. Compr. $150 \mathrm{~mm}$. Lâmina larga, triangular com o dorso convexo. Espigão longo e terminado em gancho. CUC.83.XV.36(7)

85. Id. Compr. 212 mm. Lâmina de secção triangular bastante incompleta. Cabo longo, em alvado e de secção circular. A extremidade conserva um orifício e um cravo de fixação. CUC.81. XIII.16/17(1). 
86. Espelho de fechadura. Ferro. Dim.: $32 \times 40 \mathrm{~mm}$. Placa rectangular com dois dos lados constrictos; os outros dobram-se em meia cana. Abertura rectangular. CUC.84.XV.48(1).

87. Id. Bronze. Dim.: 43X11 mm. Placa losangonal dobrada em gancho nas pontas. Abertura rectangular ladeada por dois orifícios. CUC.82.XXV.19(1).

88. Id. Dim.: $34 \times 19 \mathrm{~mm}$. Placa delgada decorada por 3 coroas circulares. Conserva dois orifícios, dois cravos e vestigios de abertura. CUC.84.XV.A6(3).

89. Disco decorativo. Bronze. Diâm. $44 \mathrm{~mm}$. Placa circular com orla retalhada e orifício a meio. CUC.82.XX.2(3).

90. Chave de tranca. Ferro. Compr. $175 \mathrm{~mm}$. Braço rectilíneo segurando três dentes que são perpendiculares. Extremidade perfurada. CUC.85.T8(2) fundo.

91. Id. Compr. $175 \mathrm{~mm}$. Semelhante ao anterior, possuindo apenas dois dentes. Extremidade perfurada. CUC.81.III.25(6).

92. Chave para aloquete. Ferro. Comp. $162 \mathrm{~mm}$. Braço de secção rectangular com um dos extremos dobrado em ângulo recto, formando um janela em U. CUC.82.XIV.21(3).

93. Chave para tranqueta. Ferro. Compr. $90 \mathrm{~mm}$. Haste de secção rectangular, com um dos extremos em anel ovalado e o outro dobrado em ângulo recto com 5 dentes. CUC.82.XX.8(2).

94. Id. Compr. $92 \mathrm{~mm}$. Semelhante ao modelo anterior. CUC.84. IX 48(2).

95. Chave rotativa. Ferro. Compr. $60 \mathrm{~mm}$. Cabo de secção circular terminado, num dos lados, por um anel espalmado e no outro, por um pé rectangular recortado. CUC.80.III.22(S/E).

96. Id. Compr. $52 \mathrm{~mm}$. Semelhante ao anterior, mas de menores proporções. CUC.81.XIII.18(2).

97. Id. Compr. $52 \mathrm{~mm}$. Semelhante às anteriores, faltando-lhe parte do anel e do cabo. CUC.80.N.1(S/E).

98. Cadeado. Ferro. Dim.: $58 \times 80 \mathrm{~mm}$. Trinco protegido por uma caixa oval com anel de segurança. CUC.84.XV.A.7(2). 
99. Id. Compr. $96 \mathrm{~mm}$. Consta de duas argolas, uma das quais interrompida, cujos extremos são paralelos ao dobrarem-se em ângulo recto. Estas pontas faziam parte do trinco. CUC.83.XIII. Banq. Sul 16/17(3d).

100. Aplicação. Ferro. Dim.: 110x36 mm. Placa rectangular com os cantos alongados em fita, enrolados em hélice na extremidade. Conserva rebite a meio da placa. CUC.83.XIV.48. Banq. Sul(1).

101. Id. Dim.: $72 \times 25 \mathrm{~mm}$. Placa munida de um orifício para alojamento do rebite. CUC.83.XIV. 48. Banq. Sul(1).

102. Estilete. Ferro. Compr. $102 \mathrm{~mm}$. Haste ponteaguda de secção circular com um dos extremos terminado em espátula e o outro em ponta. A haste contém incisões paralelas. CUC.80.VIII.11(3).

103. Id. Comp. $143 \mathrm{~mm}$. Haste mais alongada que a anterior, sem qualquer decoração. CUC.84.XIV.46(3).

104. Balança greco-romana. Bronze. Compr. $235 \mathrm{~mm}$. Peso: 22,6 grs. Travessa horizontal, de braços iguais, com um deles marcado por 12 golpes. Fiel trapezoidal. CUC.84.XV.A.7(2).

105. Prato. Bronze. Diâm. $33 \mathrm{~mm}$. Alt. $8 \mathrm{~mm}$. Concha com 3 pequenos orifícios para suspensão. CUC.84.XV.47. Banq. Sul(1).

106. Peso. Chumbo. Alt. $30 \mathrm{~mm}$. Larg. $18 \mathrm{~mm}$. Peso: 26,9417 grs. De forma prismática, perfurado no topo por um orifício. Tem valor real de 286,1 grs., valor aproximado de uncia (1 onça). CUC.81.X.5 Banq. Este(1).

107. Id. Alt. $72 \mathrm{~mm}$. Larg. máx. $32 \mathrm{~mm}$. Peso: 286,1 grs. De forma prismática, perfurado no topo por um orifício. Peso: 286,1 grs., valor aproximado do deunx (11 onças). CUC.80.15D(4).

108. Apagador/Espevitador. Bronze. Compr. $102 \mathrm{~mm}$. Haste de secção rectangular, terminando num cone oco e encimado por um pequeno gancho. CUC.84.IV.2(1).

109. Id. Compr. $117 \mathrm{~mm}$. Semelhante ao anterior, só que a ponta terminal do cone é recta e de secção rectangular. CUC.82.XX.3(3).

110. Boneca. Osso. Compr. $134 \mathrm{~mm}$. Figura feminina estilizada com os traços fisionómicos bem definidos. Ombros perfurados para a passagem de um fio. CUC.81.111.35(4). 
111. Máscara. Argila. Dim. : 32 X $25 \mathrm{~mm}$. Restam da cabeça feminina os olhos, o nariz, a boca semiaberta e o maxilar bem torneado. CUC.83.XIV. Banq. Este(4).

112. Braço. Argila. Compr. $50 \mathrm{~mm}$. Membro superior direito inflectido, tendo a mão semi-aberta. CUC.82.XXIV.34(4).

113. Campainha. Bronze. Alt. $55 \mathrm{~mm}$. Larg. máx. $40 \mathrm{~mm}$. Pirâmide truncada coroada por um anel poligonal e base ovalada. CUC.83. XXIV.22(1).

114. Guizo. Prata amoniacal. Alt. $20 \mathrm{~mm}$. Conserva parte da calote esférica superior recortada por 2 orifícios. Rematado no topo por um anel prismático. CUC.83.XXIV.templo(S/E).

115. Prego. Ferro. Compr. $171 \mathrm{~mm}$. Cabeça cónica, haste larga e de secção rectangular. CUC.81.XIV.18(2A).

116. Id. Bronze. Compr. $91 \mathrm{~mm}$. Semelhante ao anterior, mas de menores proporções. CUC.80.S 14C(3).

117. Id. Ferro. Compr. $159 \mathrm{~mm}$. Cabeça cónica achatada e larga com haste de secção rectangular. CUC.83.XV.28(1).

118. Id. Compr. $165 \mathrm{~mm}$. Semelhante ao anterior, só que a haste está dobrada em L. CUC.82.V 45(1).

119. Id. Compr. $146 \mathrm{~mm}$. Cabeça cónica achatada e larga. Haste de secção circular. CUC.84.X.32(1).

120. Id. Compr. $111 \mathrm{~mm}$. Cabeça cónica achatada de base plana. Haste dobrada na ponta em L e de secção rectangular. CUC.80. 111.24(2).

121. Id. Compr. $125 \mathrm{~mm}$. Cabeça plana e circular. Haste de secção rectangular, estando dobrada junto à ponta. CUC.84.XX.49(3).

122. Id. Compr. $57 \mathrm{~mm}$. Cabeça circular e de base plana. Haste de secção circular. CUC.82.XIV.34(1).

123. Id. Comp. $28 \mathrm{~mm}$. Semelhante ao anterior. Haste de secção poligonal. CUC.82.V 44(1).

124. Id. Bronze. Compr. $26 \mathrm{~mm}$. Cabeça circular e de base plana. Haste de secção rectangular. CUC.82.XIII.21/22(2A). 
125. Id. Ferro. Compr. $60 \mathrm{~mm}$. Cabeça larga em forma de umbo. Haste grossa, de secção circular. CUC.84.V.22. Banq. Este (2).

126. Id. Compr. $75 \mathrm{~mm}$. Cabeça cónica de base quadrangular. Haste de secção rectangular. CUC.79.S1(S/E).

127. Id. Compr. $105 \mathrm{~mm}$. Cabeça achatada de base quadrangular. Haste dobrada em L e de secção rectangular. CUC.82.IX.16(2).

128. Id. Compr. $100 \mathrm{~mm}$. Cabeça triangular e haste de secção quadrangular. CUC.84.XV. Banq. Este 41(3).

129. Prego-cavilha. Ferro. Compr. $61 \mathrm{~mm}$. Cabeça em T. Haste de secção quadrada. CUC.82.IX.16(2).

130. Id. Compr. $36 \mathrm{~mm}$. Semelhante ao anterior, mas de menores proporções. CUC.81.III.25(6).

131. Chumbadouro. Ferro. Compr. $62 \mathrm{~mm}$. Haste de secção quadrada, dobrada em L. CUC.82.XIV.49(2).

132. Id. Compr. $148 \mathrm{~mm}$. Haste de secção circular, dobrada em L. CUC.84.XV.47(3).

133. Id. Compr. $180 \mathrm{~mm}$. Semelhante ao anterior. CUC.82.XIV.23(1).

134. Grampo. Ferro. Dim.: $85 \times 70 \mathrm{~mm}$. Haste de secção quadrada dobrada em U. CUC.83.IVA.32(4).

135. Gancho. Ferro. Compr. $112 \mathrm{~mm}$. Haste de secção rectangular com um dos extremos dobrado em gancho. CUC.82.XIV.23(1).

136. Id. Compr. $130 \mathrm{~mm}$. Haste de seç̧ão rectangular com um dos extremos terminado em anel e outro formando um largo gancho. CUC.81.XIV.3/4(5).

137. Id. Compr. $145 \mathrm{~mm}$. Semelhante ao anterior, mas de maiores proporções. CUC.81.XIII.43. Banq. Este(6).

138 Cadeia de suspensão. Bronze. Compr. 115mm. Duas hastes de secção circular, unidas por meio de aneis existentes nos extremos CUC. 79 S 14B(1). 


\section{Artefactos post-romanos}

Neste capítulo incluimos objectos metálicos que nos não parecem romanos mas que poderão dar informações preciosas sobre o quotidiano da população que viveu no Convento de S. Cucufate. Não podemos, todavia, deixar de admitir a possibilidade de alguns serem anteriores ao convento fundado nos meados do séc. XII ou posteriores ao seu abandono, ocorrido no séc. Xvi. A capela continuou a servir o público pelo menos até ao séc. xvm, assistida por um ermitão. Estes objectos correspondem a níveis estratigráficos sem definição cronológica segura.

O protector $n .{ }^{\circ} 139$ e as ferraduras n. ${ }^{\text {os }} 140-145$ serviam para a protecção do casco das montadas e dos animais de carga. O modelo de ferradura variava segundo a natureza do animal e dos serviços que este prestava ao homem. Essa a razão pela qual constatamos diferenças nos exemplares ilustrados (n.os 140-145). Os n. ${ }^{\text {os }} 140-142$ têm os ramos separados e as craveiras rectangulares, enquanto os n. ${ }^{\text {os }} 143-145$ apresentam os ramos unidos com craveiras circulares e uma abei tura a meio, larga e circular. Por outro lado, a face superior do $\mathrm{n} .{ }^{\circ} 140$ desenha uma larga meia-lua, enquanto que os $n .{ }^{\circ}$ 141-142 apresentam uma curvatura mais apertada. Esta diferença deve-se ao facto de aquela ser usada para a ferração de equídeos, enquanto que os outros dois modelos se adequavam mais ao estilo do pé do gado muar e do bovino $\left({ }^{104}\right)$. As ferraduras n.os 143-145 destinavam-se, em regra, à ferração do gado muar. As ferraduras com os ramos separados aparecem regularmente entre os períodos pré-claudiano e a época medieval ${ }^{\wedge 5}$ ); os outros modelos (n.os 143-145) não devem ser anteriores aos sécs. ix-x (106).

Os n. ${ }^{\text {os }}$ 146-148 são instrumentos de costura necessários à confecção de vestuário: duas tesouras e um dedal. Os ramos

(104) Cf. Mello (D. António José de), Manual de Ferrador, Lisboa, 1885 , p. 49.

(105) Cf. Fouilles de Conimbriga, VII, p. 104.

(106) Cf. Du pont (Jean-Claude), L'artisan forgeron, Québec, 1979, Est. XXXII-XXXIII. 
triangulares do n. ${ }^{\circ} 146$ são, ao contrário do n. ${ }^{\circ} 147$, fortes e bastante largos, o que permitiria ao alfaiate o corte de tecido mais encorpado. Conhecemos um modelo semelhante do séc. xiv $\left({ }^{107}\right) ;$ o ${ }^{\circ}{ }^{\circ} 147$, pelo seu fino recorte decorativo, serviria para trabalhos de costura mais delicados. Esta peça de ferro tem, a decorá-la, embutidos de latão, tão em voga nos sécs. xvm-xix $\left({ }^{108}\right)$. O n. ${ }^{\circ} 148$ é um dedal. Este objecto surge com frequência na Idade Média, conforme nos atestam os exemplares de Lincolnshire $(109 * *)$, datáveis do séc. xi; conhecemos, no entanto, um exemplar de Fishbourne, datável entre 100-280 d. C. (no).

$\mathrm{O}$ n. ${ }^{\circ} 149$ é um utensílio de percussão circular (m), em ferro, apropriado para furar madeira. É usado tanto por carpinteiros como por tanoeiros. Este trado ou verruma termina em pua, seguindo-se-lhe uma larga meia cana para receber a serradura ao furar a madeira (112). O seu encabamento consistia num espigão fixo a uma travessa de madeira perpendicular ao plano do cabo.

A turquês é um instrumento de preensão $\left(n .^{\circ} 150\right)$ usado para o arranque de pregos ou de fios metálicos. Esta peça é muito semelhante a um exemplar galo-romano de Bourges (113), só que a natureza do ferro do $\mathrm{n}^{\circ} 150$ denuncia um fabrico bem mais recente $\left({ }^{114}\right)$. Este instrumento é usado tanto na carpintaria, coudelaria, serralharia, como em oficinas de curtumes $\left({ }^{115}\right)$.

(i7) cf CASElli (Giovanni), O Império Romano e a Idade Média, São Paulo, 1982, p. 46, n. ${ }^{\circ} 12$. O autor data-o do séc. xiv.

(108) Cf. B RUnt (Andrew), Guia dos estilos de mobiliário, Lisboa, 1982, p. 28; Tr e ASE (Geoffrey), O Relógio da Historia, São Paulo, 1986, n. 30-31.

(109) Cf. Caselli (G.), op. cit., p. 38-39, n. ${ }^{\circ} 21$ (objecto feito com uma liga de cobre).

(no) Cf. CunLifFe (B.), op. cit., (V. nota 9), p. 118, fig. 51, n. os 147-148.

(m) Cf. Dupont (Jean-Claude) е Mathieu (Jacques), Les métiers $d u$ cuir, Québec, 1981, p. 34 e 40.

(112) Cf. Col a res (José Pedro dos Reis), Manual do marceneiro, Lisboa, p. $30-31$.

(113) Cf. Hofmann (B.), La Quincaillerie Antique, i. a partie, «Notice Technique», Paris, 1964, Est. VIII, n. ${ }^{\circ} 43$ (Museu de Bourges, n. ${ }^{\circ} 18$ ).

(U4) Qf Trease (G.), op. cit., (V. nota 108), p. 78, n. 13.

(115) Cf. Colares (J. P. R.), op. cit., p. 30, fig. 36; Dupont (J.-G.), op. cit., p. 44; Dupont (J.-C.) e Mathieu (J.), op. cit., (V. nota 110), p. 100 e 110 . 
$\mathrm{O}$ n. ${ }^{\circ}$ 151, em estanho prateado, sugere-nos um instrumento cirúrgico, mais exactamente, um dissecador, já usado na época romana $\left.{ }^{116}\right)$. Trata-se de uma folha estreita com uma das extremidades munidas de duas pontas ou dentes curvos. Estes serviriam para separar ou cortar qualquer órgão existente no corpo humano. Não encontramos nenhum paralelo para o $n .^{\circ} 151$, o que nos impede de o situar no tempo.

Os n. ${ }^{\text {os }}$ 152-156 agrupam objectos de carácter ornamental e religioso. $\mathrm{O} n .^{\circ} 152$ é uma medalha religiosa renascentista (fins do séc. $\mathrm{xV}$-xvi). A figura da Virgem sentada no trono e a do Menino Deus, de braços abertos, sentado no regaço de sua Mãe, retratam o estilo e o género emblemático da Virgem Majestade da Renascença $\left({ }^{117}\right)$.

As duas cruzes peitorais (n. os 153-154) correspondem a dois períodos históricos diferentes: uma (n. $\left.{ }^{\circ} 153\right)$ situar-se-á entre o séc. viu e o xu ; a outra (n. $\left.{ }^{\circ} 154\right)$ enquadra-se no séc. xvI-xvII

A cruz de ferro é bastante tosca e singela na sua nudez figurativa. A simples cruz peitoral ocorre timidamente no Alto Império Romano (118), tornando-se o seu uso frequente no séc. xn (119).

$\mathrm{O}$ n. ${ }^{\circ} 154$ representa a agonia e a morte de Cristo na cruz; de tardoz, a Imaculada Conceição.

O séc. xvi-xvi enaltece, a exemplo do séc. xv, a imagem do Cristo dramático. O corpo pende dos braços, os pés fixam-se por meio de um cravo, os joelhos flectem, a coroa circunda a cabeça e o rosto exprime dor, sofrimento e morte $\left({ }^{12 \circ}\right)$. Esta repre-

(116) Cf. Milne (J. S.) et allii, op. eit., p. 79-85, Est. XXI-XXII.

$\left({ }^{117}\right)$ Cf. Coutinho (B. Xavier), Nossa Senhora na Arte, Porto, 1959, fig. 72; Dias (Pedro) e SERR̃̃o (Yitor), A pintura, a iluminura e a gravura dos primeiros tempos do séc. XVI, in História da Arte em Portugal - O Manuelino, Lisboa, 1986 (5), p. 117-146 (p. 137 e 142).

(118) Cf. Frere (S.), op. cit., p. 132. O autor data o exemplar de 150$-155 / 160$

(119) Cf. Oliveira (A. Alves de), Cruz Litùrgica, in Enciclopédia Luso-Brasileira de Cultura, Lisboa, 1967 (6), p. 477-479 (p. 479).

$\left({ }^{12}\right)$ Cf. «The Paul Getny Museum Journal», Califórnia, voi. 15, 1987, p. 167 (missal de Mainz).

Conimbriga, 26 (1987), 133-165 
sentação de cariz renascentista poderá datar dos fináis do séc. XVI (121).

A placa de cobre dourada (n. $\left.{ }^{\circ} 155\right)$ com a estilização da flor de liz associa-se ao mobiliario religioso e ornamental do séc. xvi (122). Por outro lado, a flor de liz e a aplicação da folha dourada sobre o cobre torna-se muito frequente na arte decorativa do séc. xvi ( $\left.{ }^{123}\right)$. Julgamos que esta placa poderia ter pertencido a um relicário ou cruz processional $\left({ }^{124}\right)$.

$\mathrm{O}$ n. ${ }^{\circ} 156$ é uma tampa de estanho fundido corn a pega em forma de cruz latina. Esta tampa poderia ter pertencido a um pequeno recipiente para o incenso.

O n. ${ }^{\circ} 157$ é urna placa de cobre dourada cinzelada, para decoração de mobiliário. Esta placa revela a mesma factura técnica que a do n. ${ }^{\circ}$ 155. Tal facto leva-nos a sugerir que esta peça não deverá ser anterior ao séc. xvi-inícios do séc. xvn $\left({ }^{125}\right)$.

$\mathrm{O}$ n. ${ }^{\circ} 158$ é um fecho de cofre, em cobre prateado com decoração estampada. Não encontramos nenhum paralelo que nos permita situá-lo no tempo.

Com o n. ${ }^{\circ} 159$ ilustramos 4 alamares de prata que passaram a guarnecer o traje feminino a partir do séc. xvi $\left({ }^{126}\right)$.

Os n.os 160-161 são botões modernos do fardamento militar.

O n. ${ }^{\circ} 162$ é uma folha de oito pétalas em cobre dourado, usada certamente como ornato decorativo.

$\mathrm{O}$ n. ${ }^{\circ} 163$ é uma fivela de cobre usada como ornato do calçado masculino do séc. Xvm $\left({ }^{127}\right)$.

$\mathrm{O}$ n. ${ }^{\circ} 164$ é urna placa de cobre com desenho floral estampado. Sugere, pelo ornato e técnica de estampagem, um objecto bastante moderno. Este berloque teria pertencido a um colar, a uma luneta ou a um relógio de bolso?

(121) Cf. Nogueira Gonçalves (A.), Crucifixo, in Enciclopédia Luso-Brasileira de Cultura, Lisboa, 1967(6), p. 466-468.

(122) Cf. $\mathrm{D}_{\mathrm{IAS}}$ (P.), As artes decorativas, in Historia de Arte em Portugal, 4, Lisboa, Alfa, 1986, p. 139-158 (p. 150).

(123) Cf. BRUnt (A.), op. cit., p. 23.

(124) Cf. Dias (P.), op. cit., p. 148 e p. 150.

(125) Cf. BRUnt (A.), op. cit., p. 23.

(126) Cf. Historia do Trajo em Portugal, Porto, p. 32 e 36.

(127) Cf. id., ibidem, p. 49. 
139. Protector. Ferro. Dim.: 50x20 mm. Placa em meia lua com um espigão na face posterior. CUC.81.XII.3(S/E).

140. Ferradura. Ferro. Gompr. $120 \mathrm{~mm}$. Peso: 199,02 grs. Placa em U, cujos ramos contêm 3 aberturas rectangulares. GUC.79.S7(3)

141. Id. Gompr. $110 \mathrm{~mm}$. Peso: 110,45 grs. Curvatura da placa mais estreita que a anterior, apresentando seis aberturas rectangulares. GUG.79.III.34(1).

142. Id. Gompr. 106 mm. Peso: 66,34 grs. Semelhante à anterior, só que a curvatura entre os ramos é mais larga. GUC.79.VII(S/E).

143. Id. Gompr. 76 mm. Peso: 127,09 grs. Placa com os ramos unidos, formando a meio uma abertura circular; aquela contém seis aberturas circulares. CUC.80.S 14C(1).

144. Id. Gompr. $81 \mathrm{~mm}$. Peso: 63,63 grs. Semelhante às anteriores, só que a abertura entre os ramos é oval. CUC.79.VII.Res(S/E).

145. Id. Gompr. 106 mm. Peso: 40,11 grs. Semelhante à anterior, mas de maiores proporções. CUG.79.XIII.7(1).

146. Tesoura. Ferro. Gompr. $167 \mathrm{~mm}$. Ramo formado por uma lâmina triangular e perna rematada por um anel. A lâmina conserva o orifício para o pino. CUC.79.VII.42(1).

147. Id. Ferro e latão. Compr. $168 \mathrm{~mm}$. Peça completa com fio de latão incrustado nas duas pernas da tesoura; pé e sextafólio de latão a decorar o pino, em ferro. CUC.79.S1(S/E).

148. Dedal. Liga de cobre. Alt. $20 \mathrm{~mm}$. De forma cilindrica com o topo cónico. CUC.80.VIII.7(2).

149. Verruma. Ferro. Gompr. $190 \mathrm{~mm}$. Haste de secção quadrangular com um dos extremos terminado em espigão e o outro em hélice. CUC. 79. XVIII (S/E).

150. Turquês. Ferro. Alt. $114 \mathrm{~mm}$. Braço esquerdo munido de orifício e com o topo terminado em pinça. GUG.82.IV.25(1).

151. Instrumento cirúrgico? Bronze estanhado. Gompr. $205 \mathrm{~mm}$. Haste de secção rectangular com um dos extremos terminado em duas garras encurvadas. CUC.80.XVIII(S/E). 
152. Medalha religiosa. Bronze. Dim.: $38 \times 26 \mathrm{~mm}$. De forma oval, representa no anverso a Virgem sentada no trono com o Menino Deus sentado no regaço; no reverso, um anjo, de frente com o braço direito inflectido e o dedo indicador apontado para o céu. CUC.84.IX.43. Banq. Este(2).

153. Cruz peitoral. Ferro. Dim.: $55 \times 37 \mathrm{~mm}$. Braços desiguais e incompletos; um dos extremos do braço maior termina em gancho. CUC.79.S1(S/E).

154. Crucifixo. Bronze. Dim.: $67 \mathrm{X} 45 \mathrm{~mm}$. Cristo crucificado, tendo no topo a inscrição na cartela: INRI (IESVS NAZARENVS REX IVDAEORVM); aos pés, uma caveira. O reverso da cruz representa a Imaculada Conceição, com o atributo da lua crescente aos pés. CUC.79.S1(S/E).

155. Placa decorativa. Cobre dourado. Dim. 53X43 mm. Chapa cruciforme decorada corn a flor de liz estilizada, aberta por meio de cinzel; a meio é recortada por um óculo oval, delimitado por 4 orifícios de fixação. CUC.79.N1O(S/E).

156. Tampa. Estanho. Alt. $10 \mathrm{~mm}$. Diâm. base: $37 \mathrm{~mm}$. De forma prismática, com base oitavada e facetada. O topo é munido de uma pega representando uma cruz latina. CUC.80.XVIII.9/10(S/E).

157. Placa decorativa. Cobre dourado. Dim.: 52x26 mm. Placa rectangular com decoração geométrica incisa; a meio é recortada por urna abertura ovalada, sendo esta rodeada por 8 pequenos orifícios de fixação. CUC.79.S1(S/E).

158. Fecho de cobre. Cobre prateado e ferro. Dim.: $32 \times 18 \mathrm{~mm}$. Lingueta escudiforme com um dos extremos em charneira; esta conserva o eixo em ferro; nela fixa-se o espelho rectangular com decoração geométrica estampada. CUC.81.XII.41/42(1).

159. Quatro alamares. Prata. Dim.: 30x16 mm. Cada um deles consta de dois anéis afrontados unidos por meio de uma fita soldada. CUC.80.VIII.13(3).

160. Botão. Liga de cobre. Alt. $5 \mathrm{~mm}$. Diâm. $14 \mathrm{~mm}$. Cabeça circular com pedúnculo semicircular. CUC.81.VIII.12. Banq. Sul(1).

161. Id. Alt. $14 \mathrm{~mm}$. Diâm. $16 \mathrm{~mm}$. Semelhante ao anterior, mas de maiores proporções. O pedúnculo é trapezoidal. CUC.82.V.49(1). 
162. Folha decorativa. Liga de cobre dourada. Diâm. $28 \mathrm{~mm}$. Chapa oitavada. CUC.82.XIV.25(3).

163. Fivela. Latão. Dim.: $51 \mathrm{X} 23 \mathrm{~mm}$. Placa rectangular com os lados menores formando dois apêndices parabólicos. O travessão mediano fixa o fusilhão. CUC.79.XIII.(S/E).

164. Berloque. Liga de cobre. Dim: $35 \mathrm{~mm}$. Placa com decoração floral estampada, tendo no reverso 2 ganchos de fixação; um deles suporta um elo em cadeia formado por 4 anéis ovais. CUC. 80. $\mathrm{Nl} / 2(\mathrm{~S} / \mathrm{E})$. 
EST. I
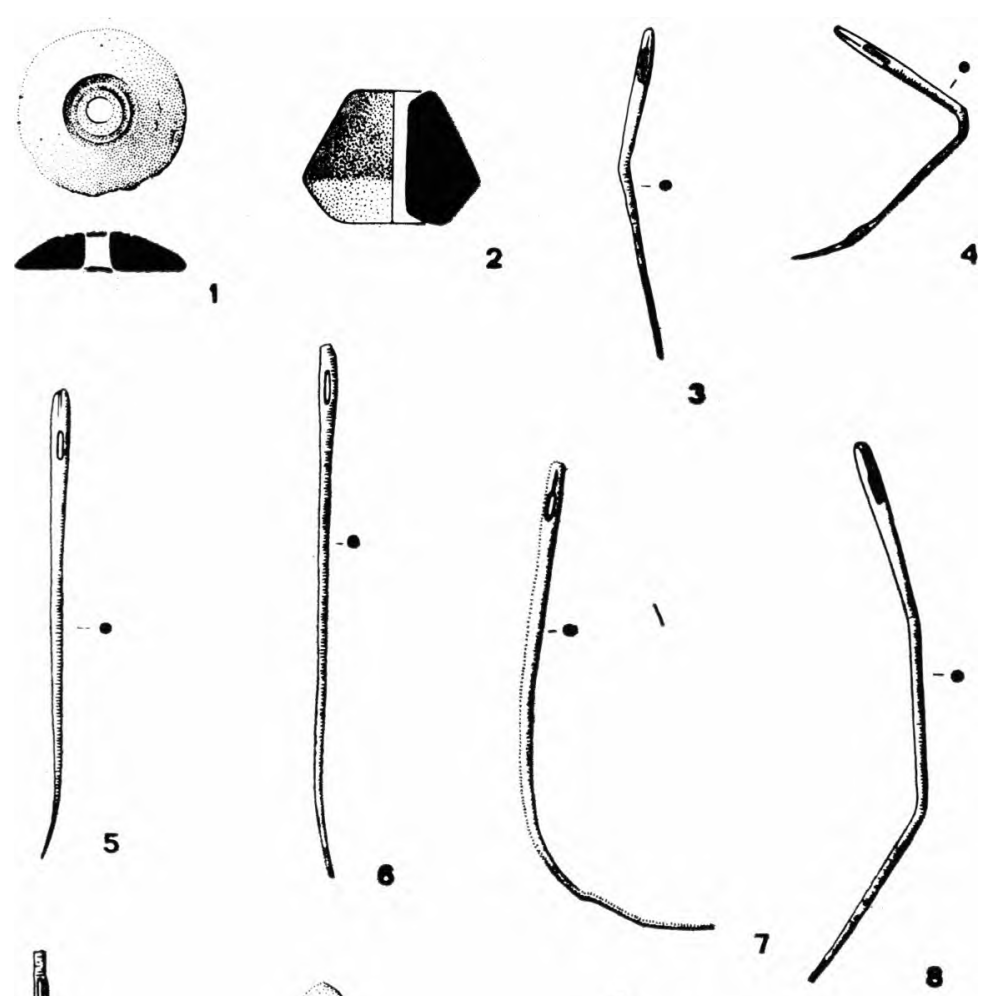

3

4

I

2
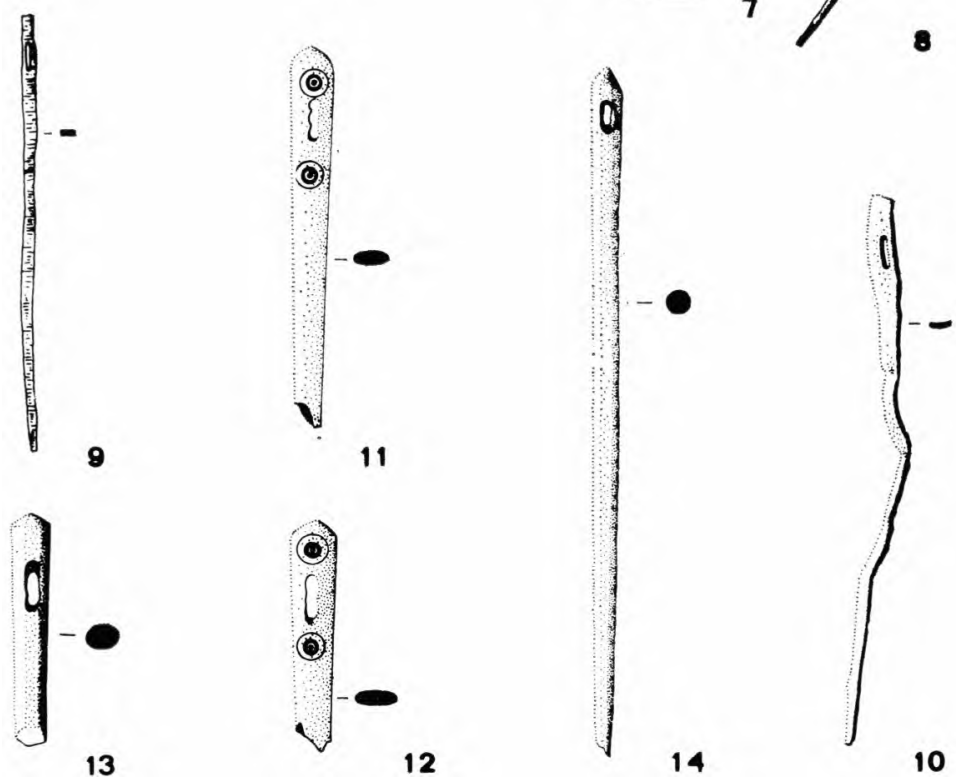

Esc. 2:3 
Est. II
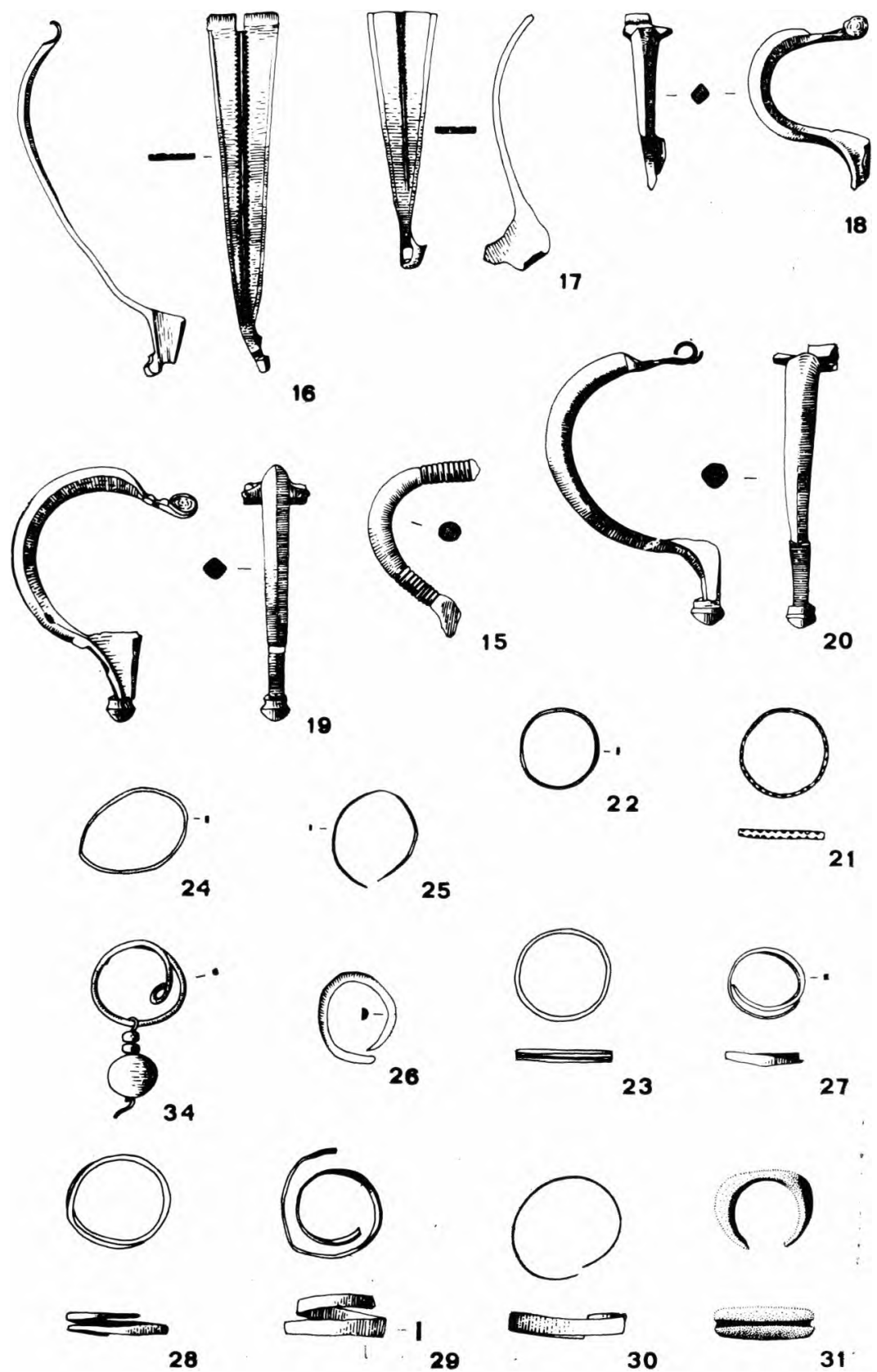

Esc. 2:3 
EsT. Ill

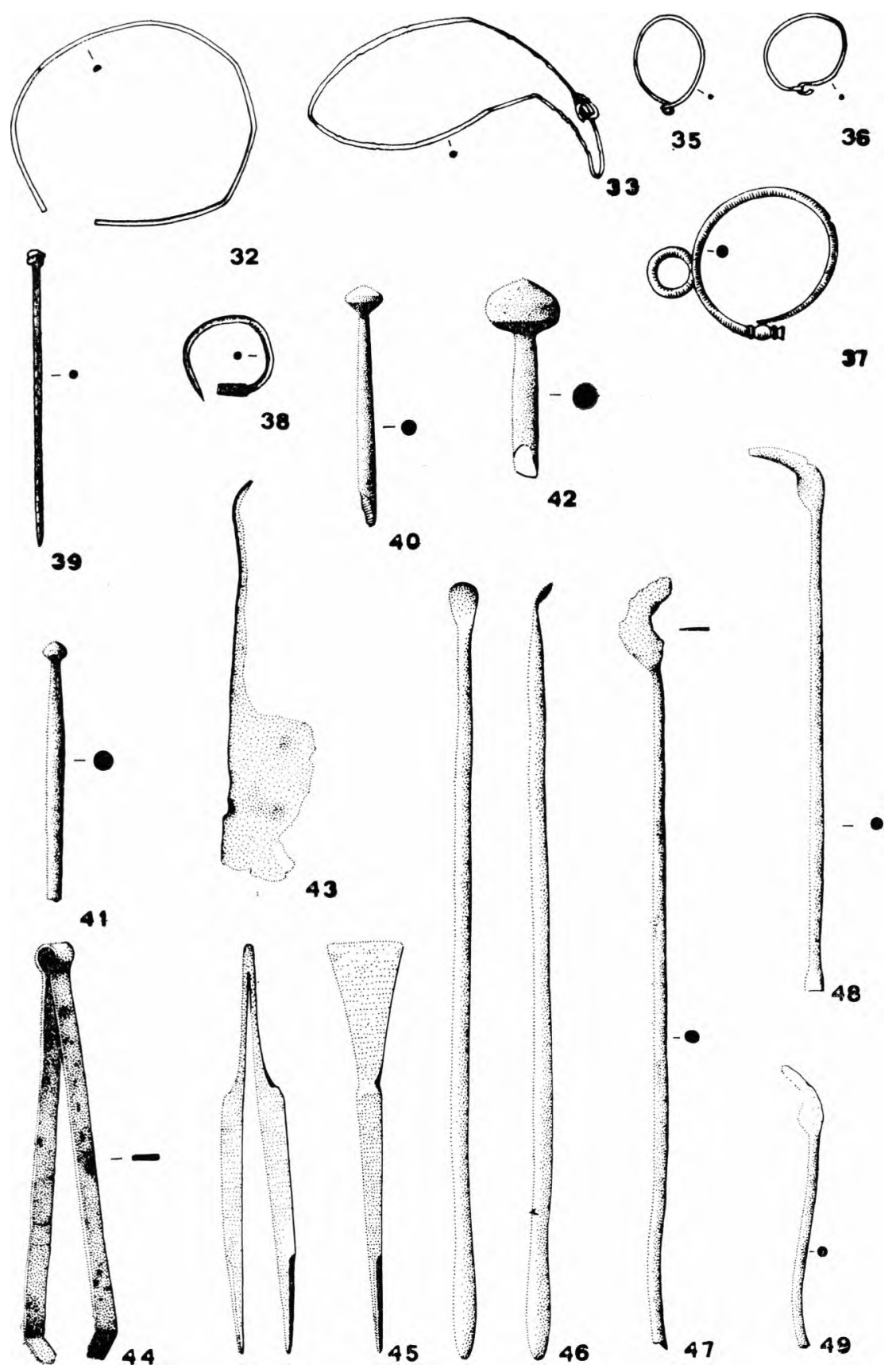

Esc. 2:3 
EsT. IV

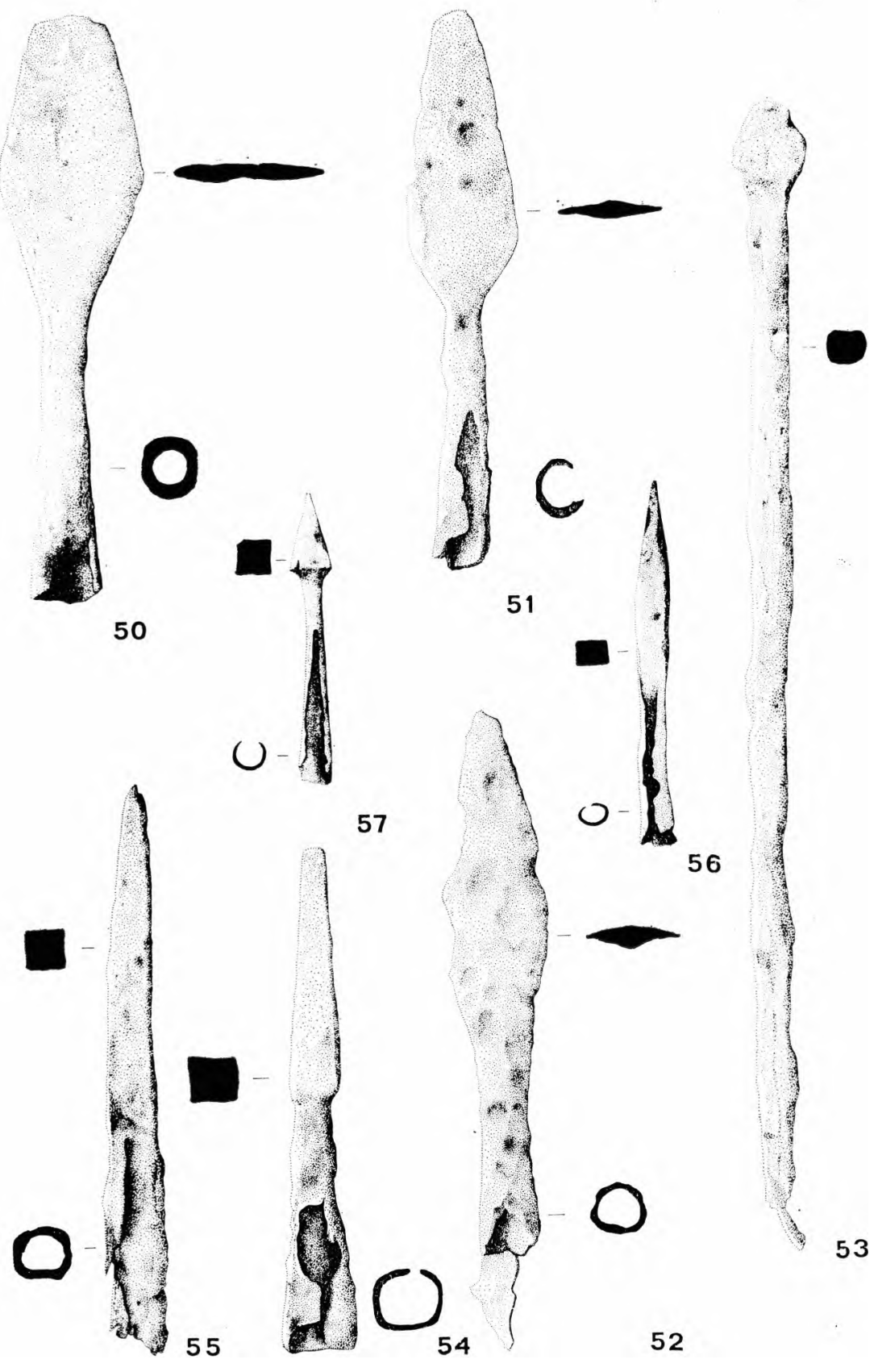

Esc. 2:3 
Est.' V

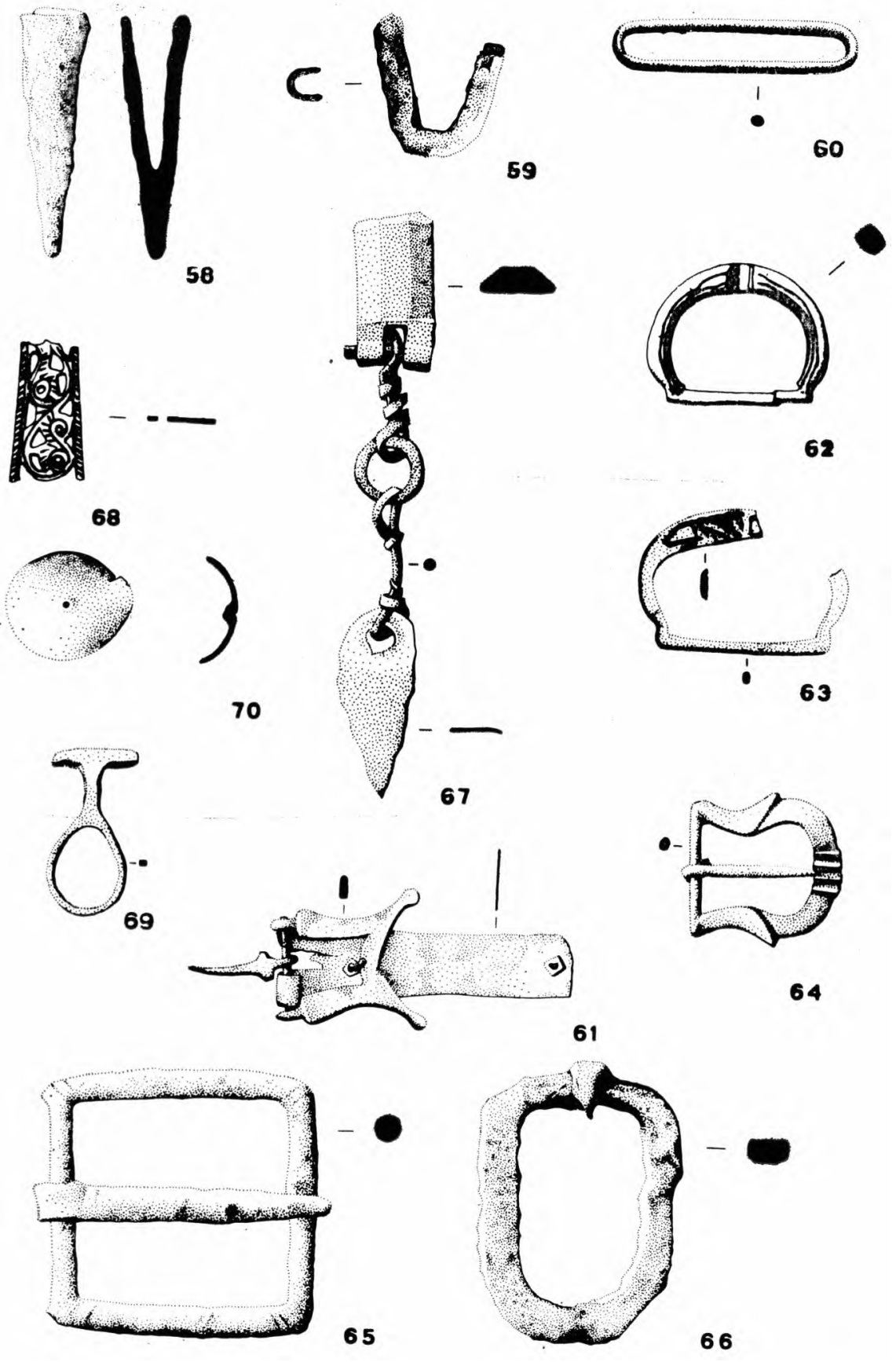

Esc. 2:3 
EST. VI
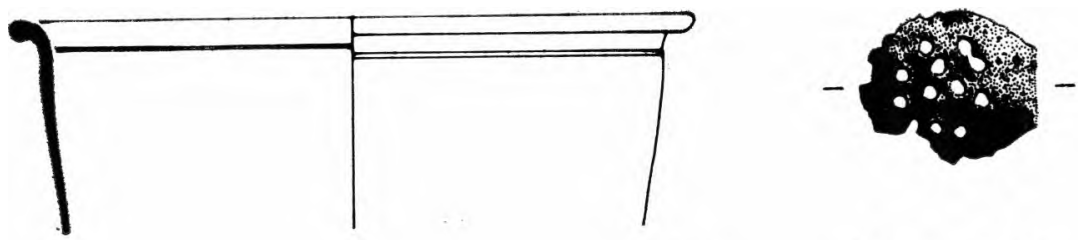

73

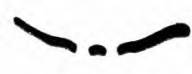

74
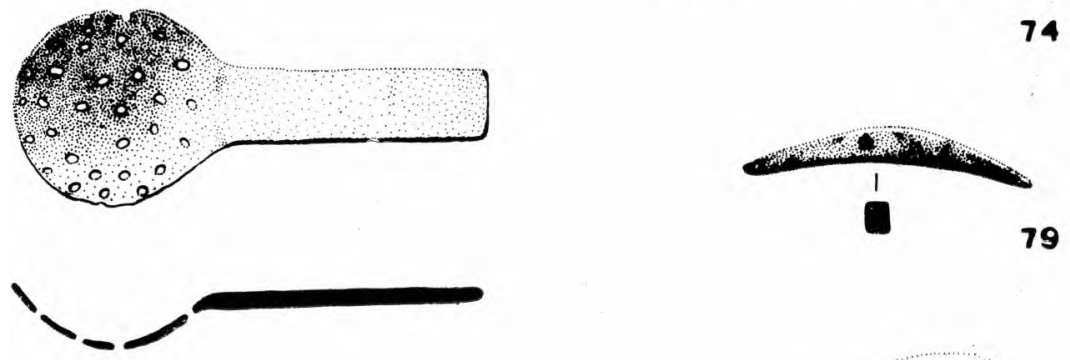

75
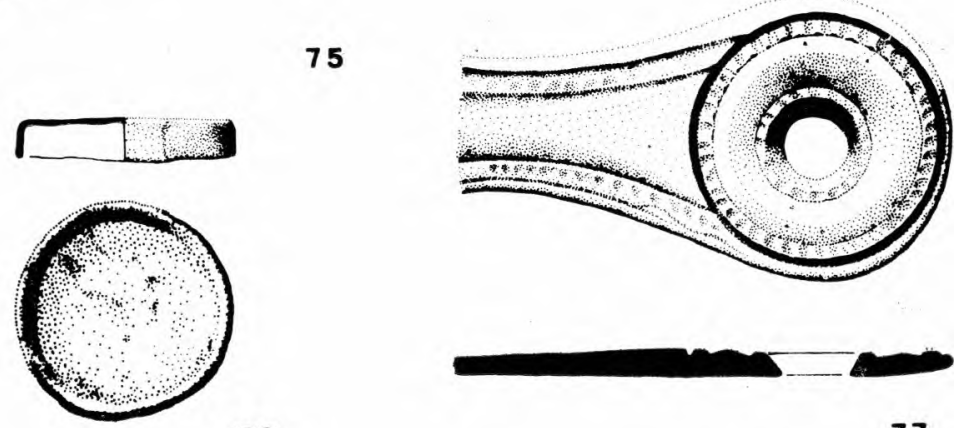

7.
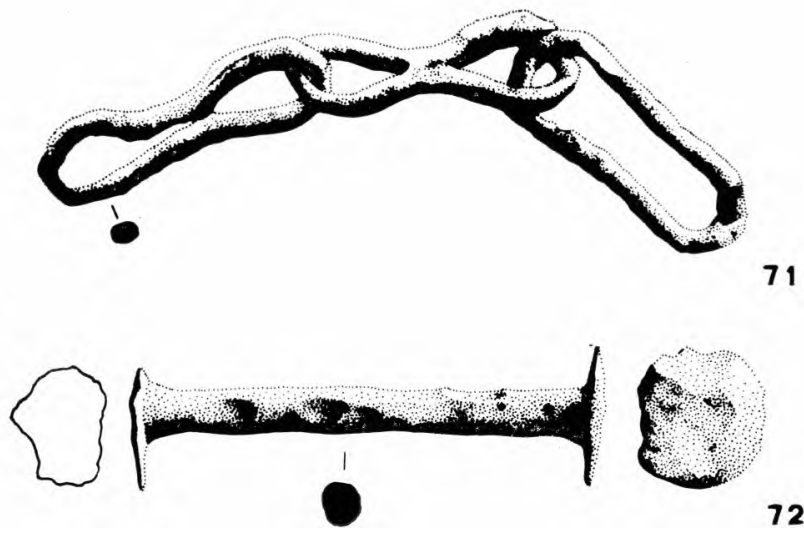

Esc. 2:3 
EST. VII
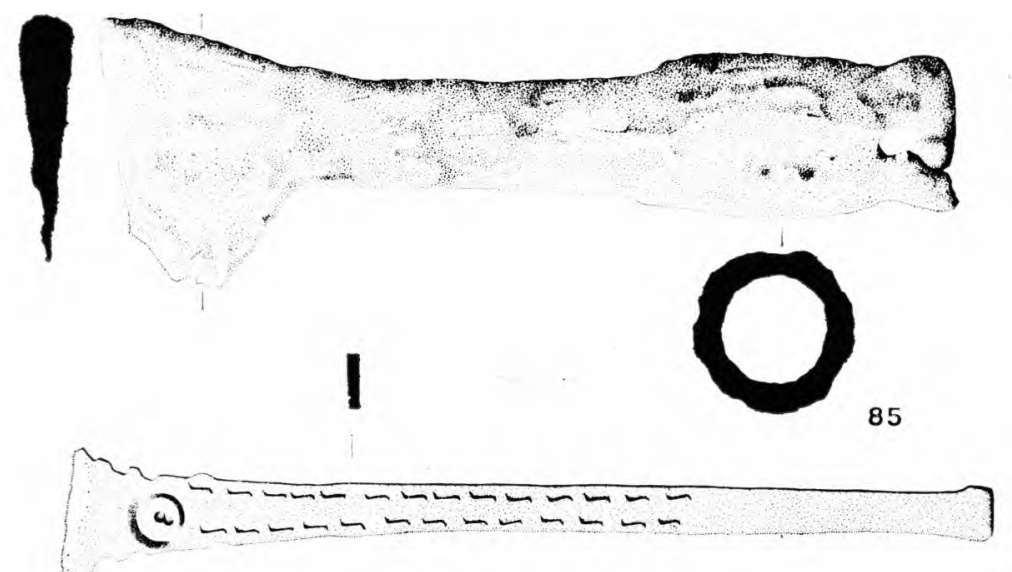

76

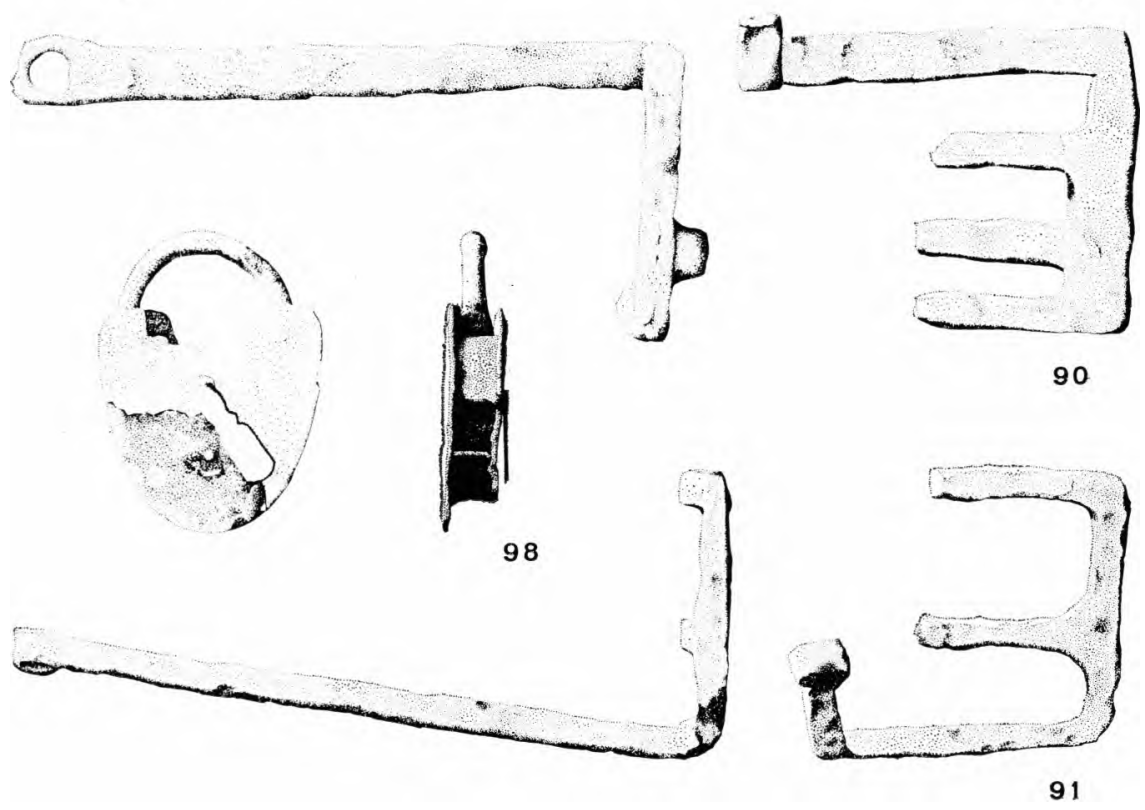

Esc. 2:3 
EST. VIII
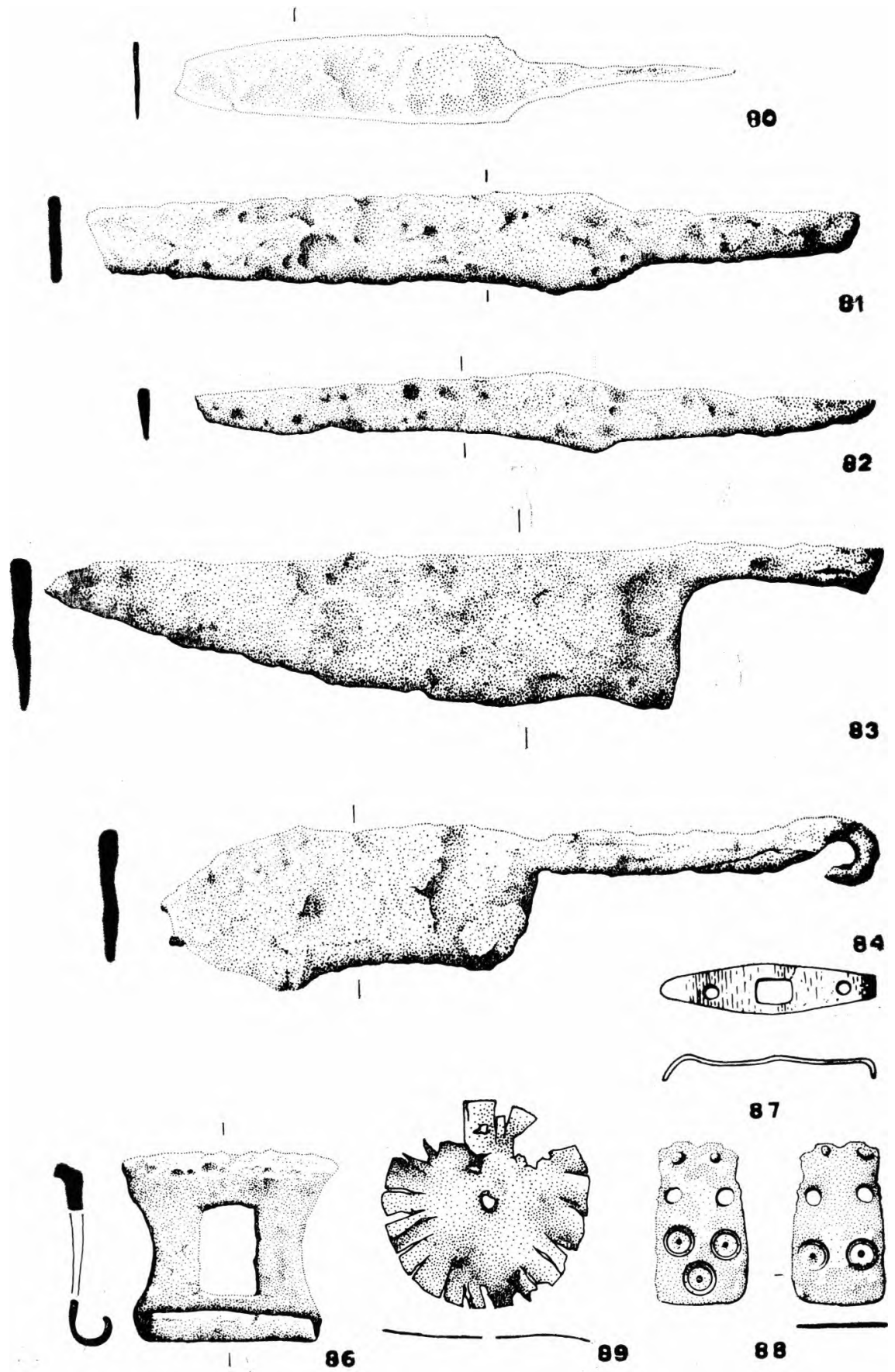

Esc 2:3 
EsT. IX
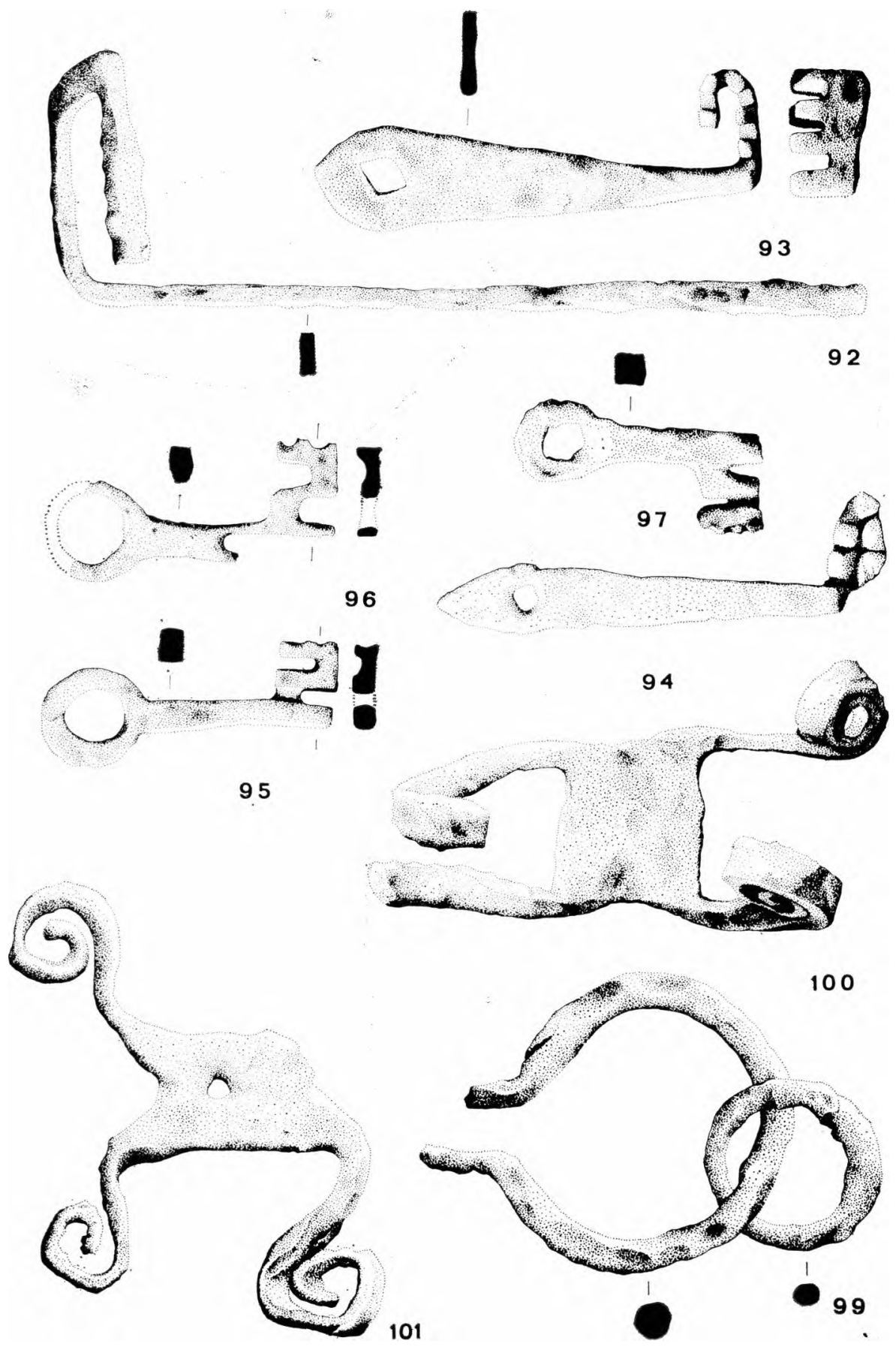

Esc. 2:3 
EsT. X

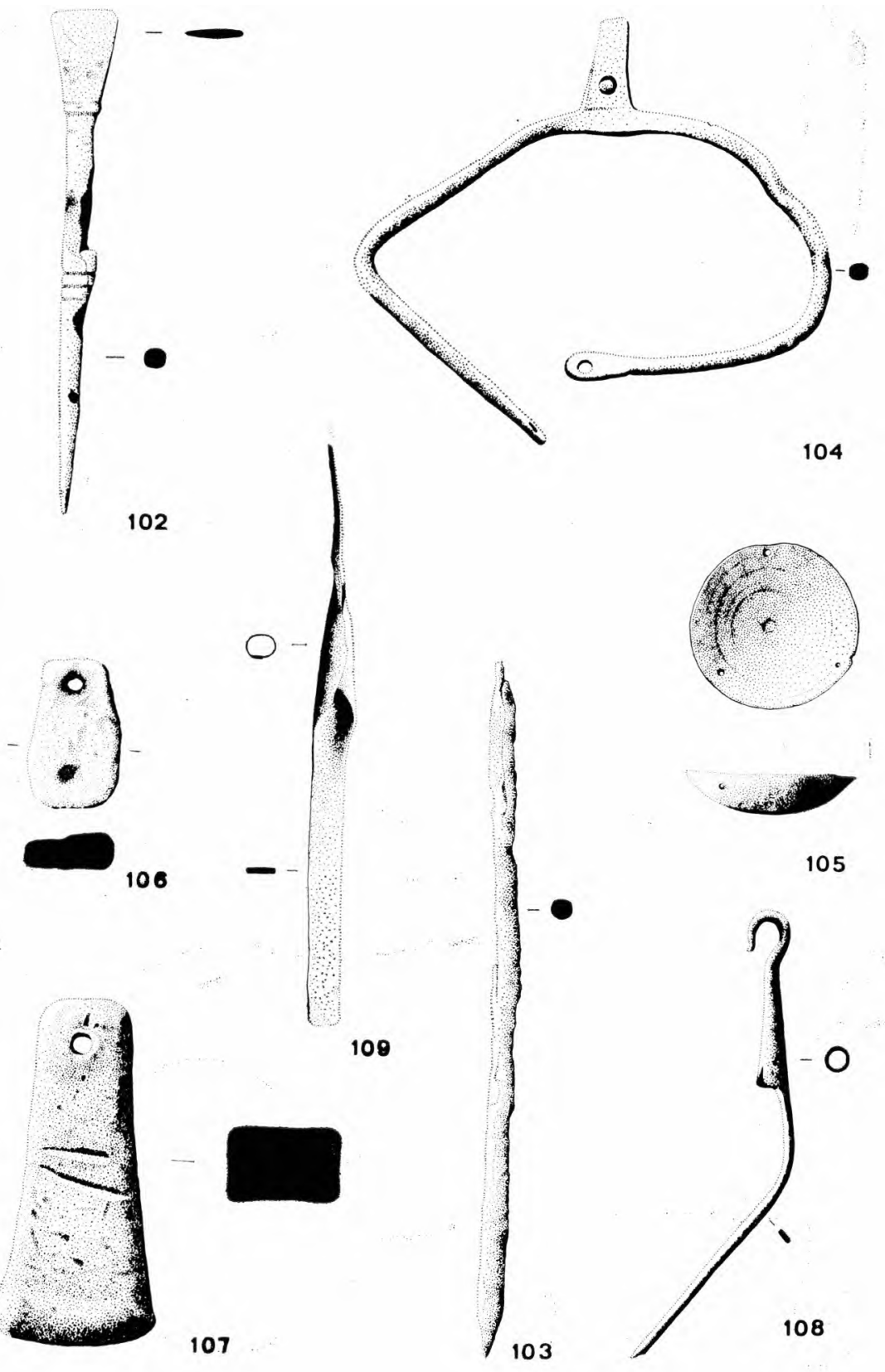

Esc. 2:3 
Est. XI
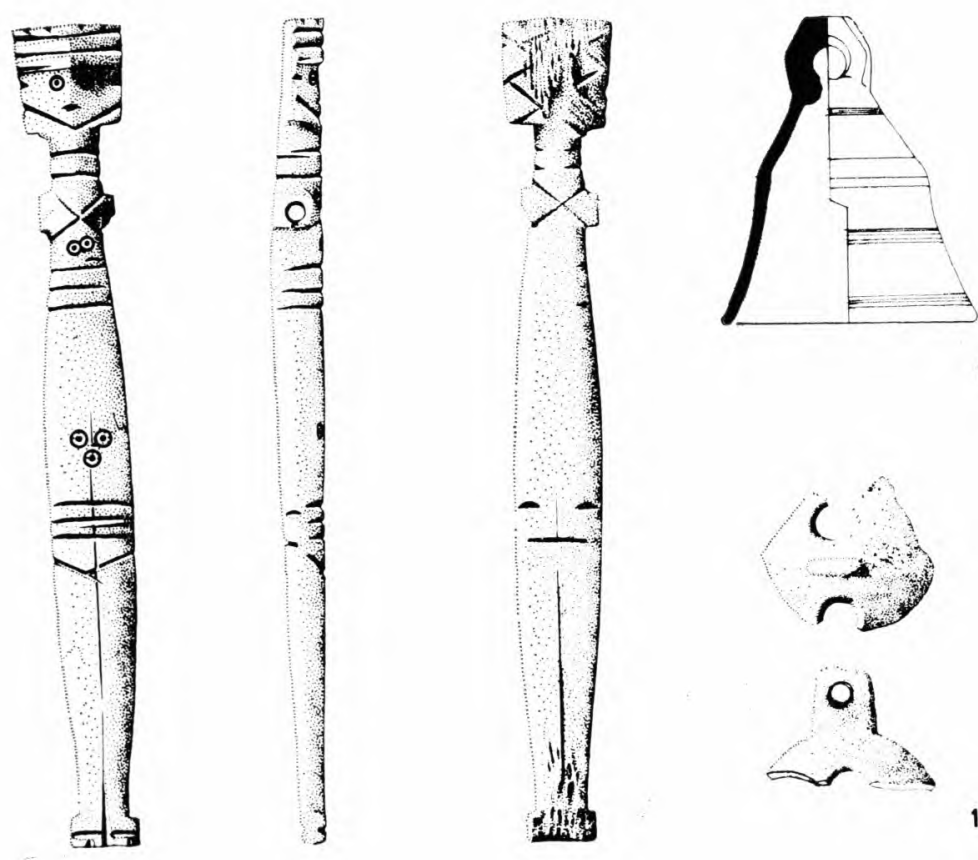

113

110
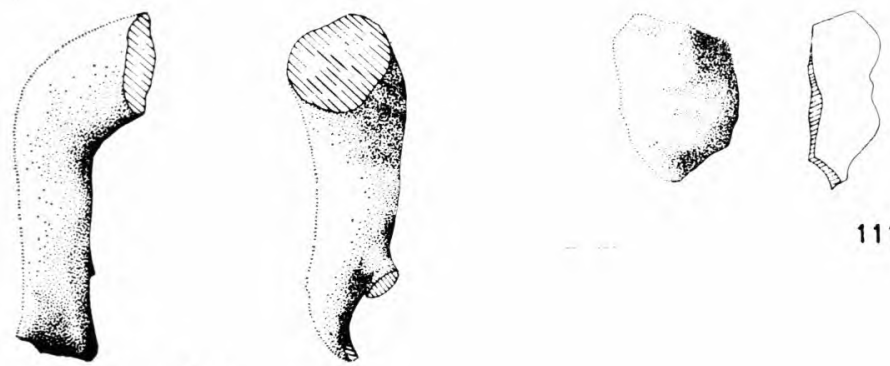

111

112

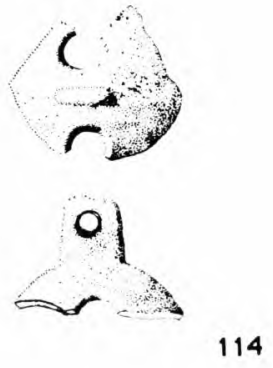

Esc. 2:3 
EsT. XII

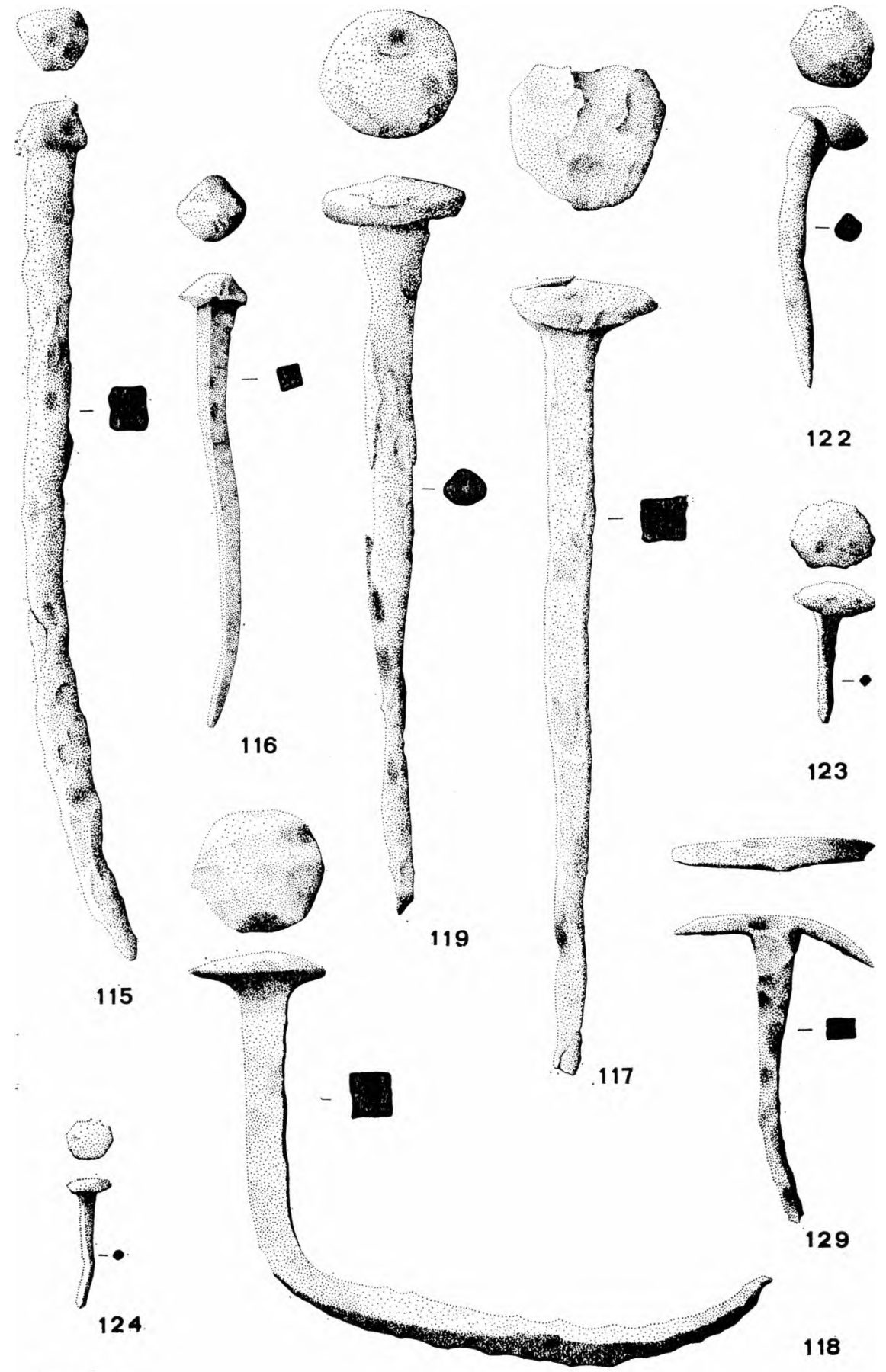

Esc. $2: 3$ 


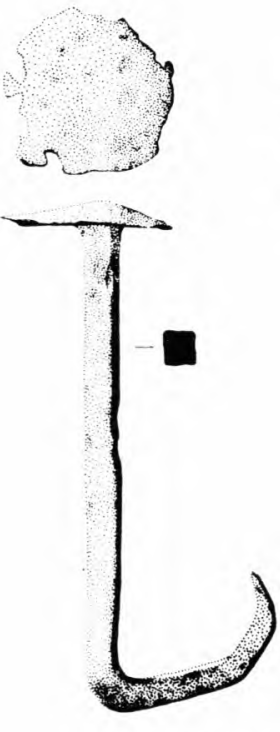

120
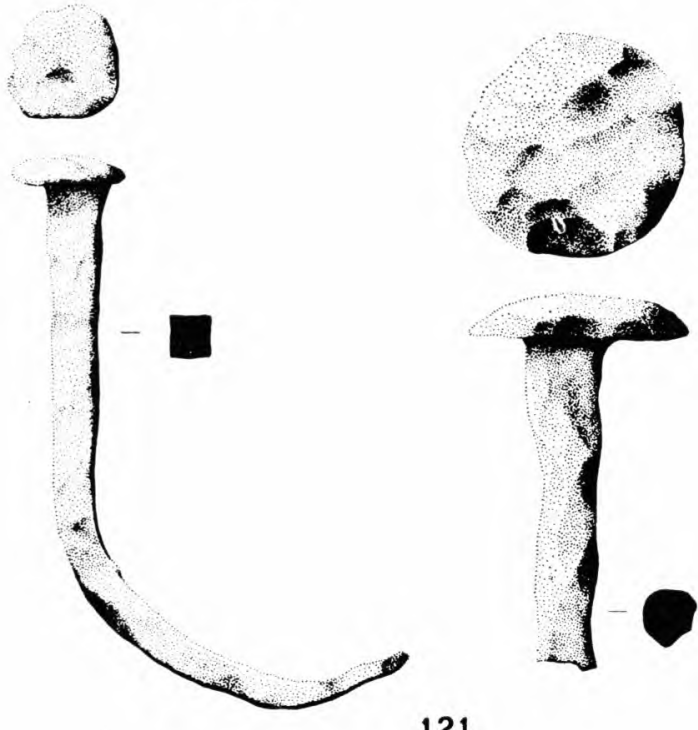

125
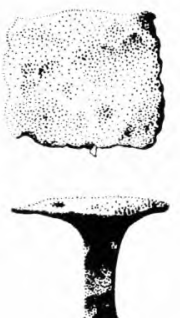

127

126

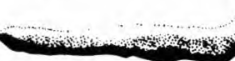

$-1$
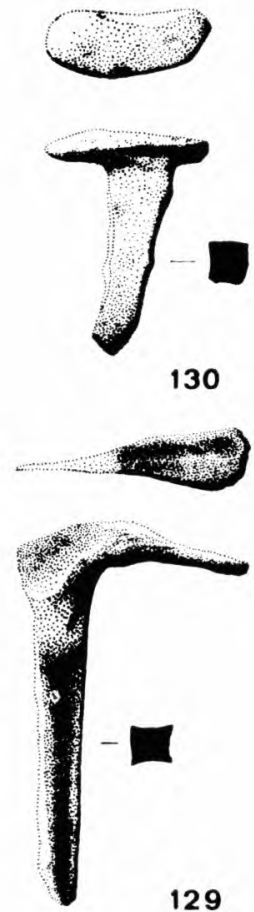

129
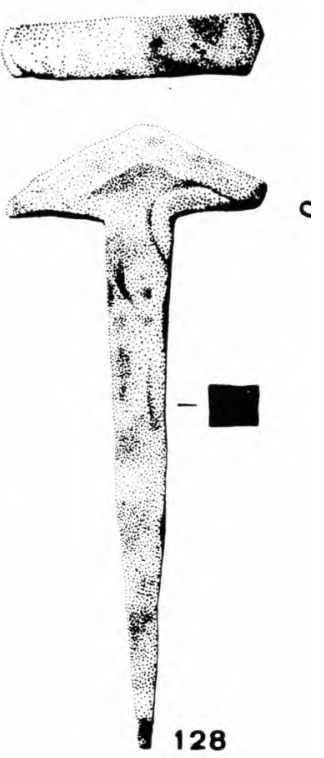

Esc. 2:3

138

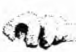

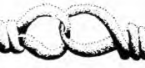


EsT. XIV

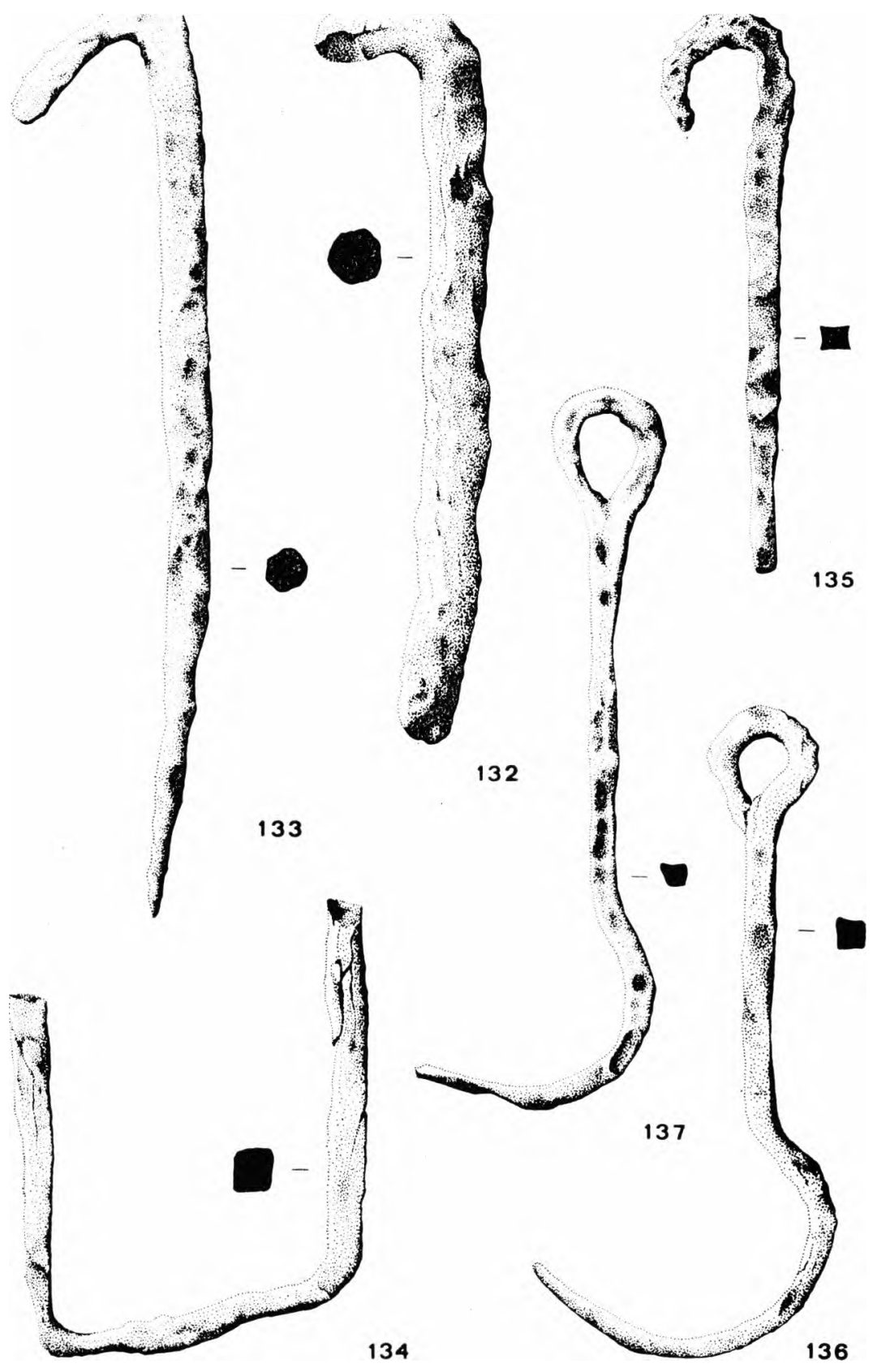

Esc. 2:3 
Est. XV
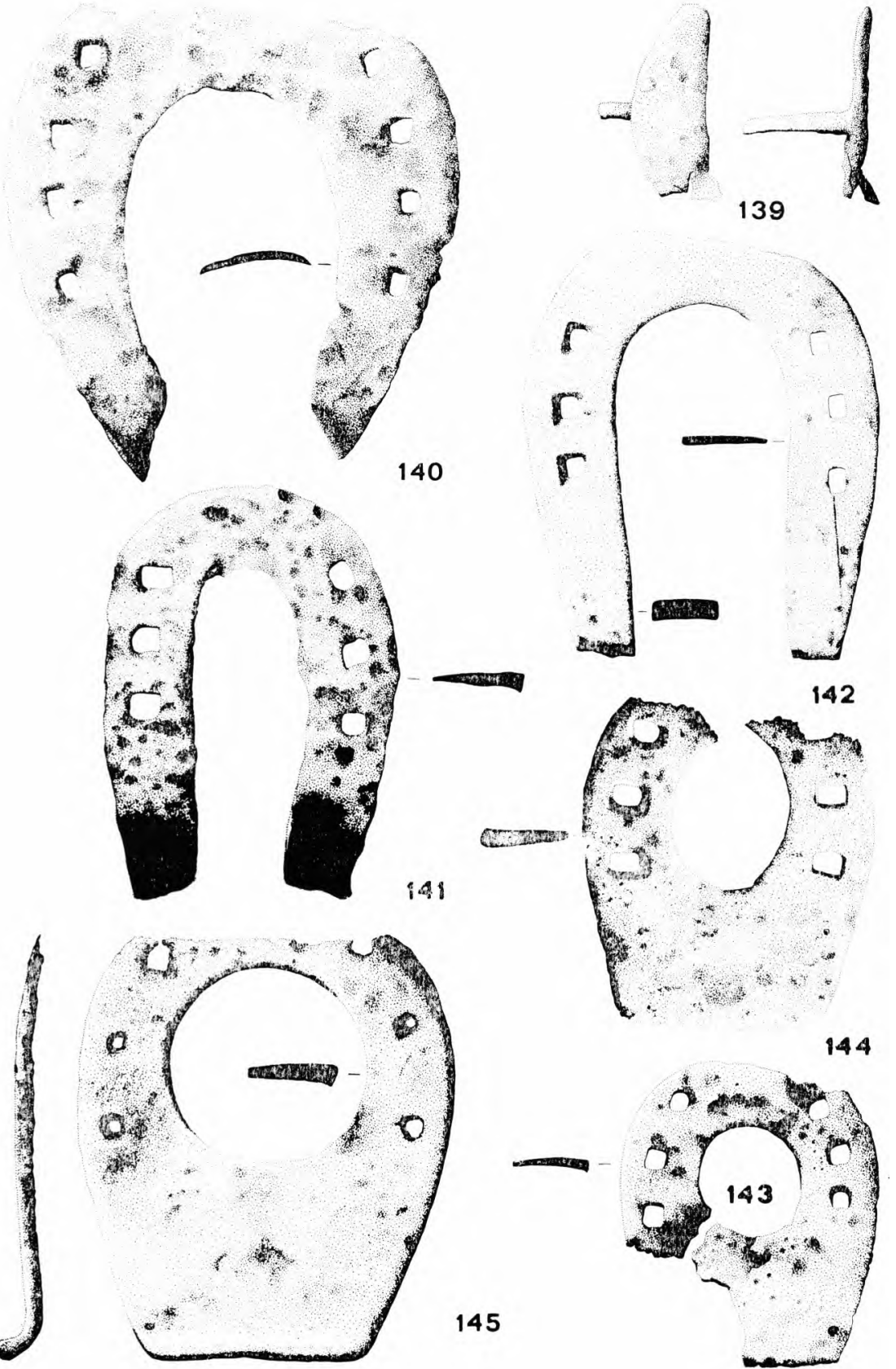

is
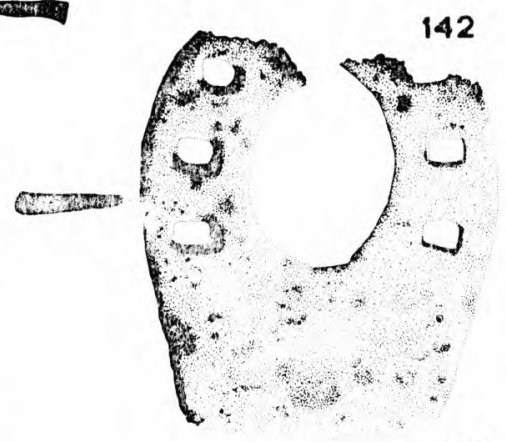

144

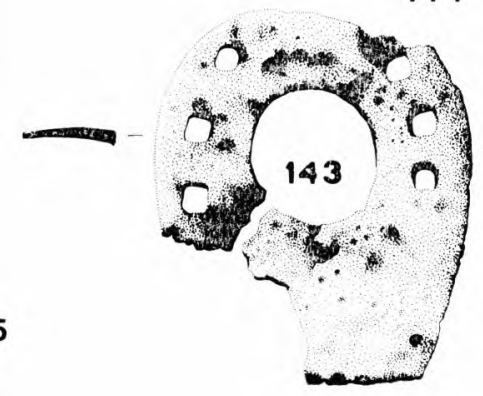

Esc. 2;3 

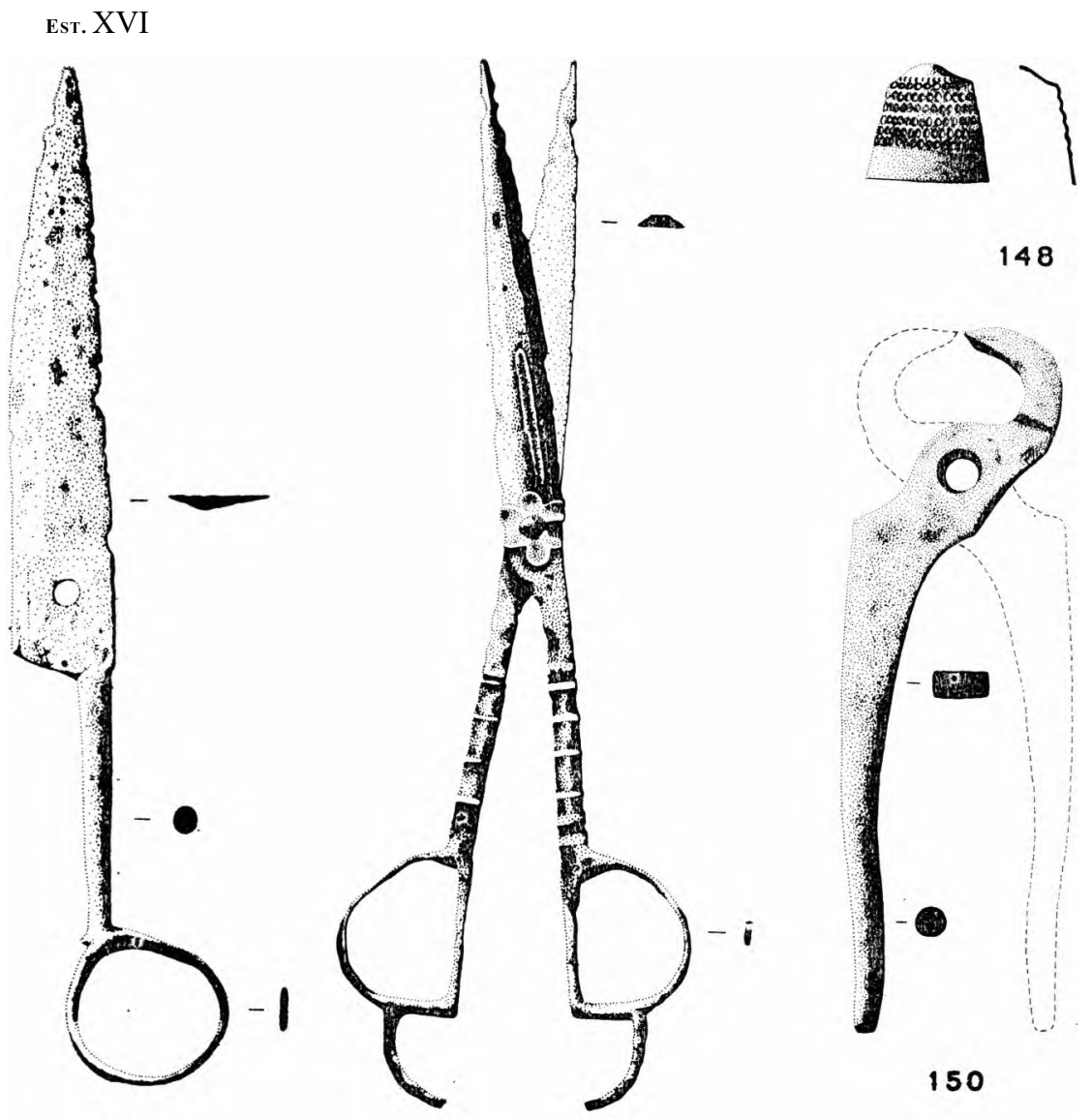

$$
148
$$
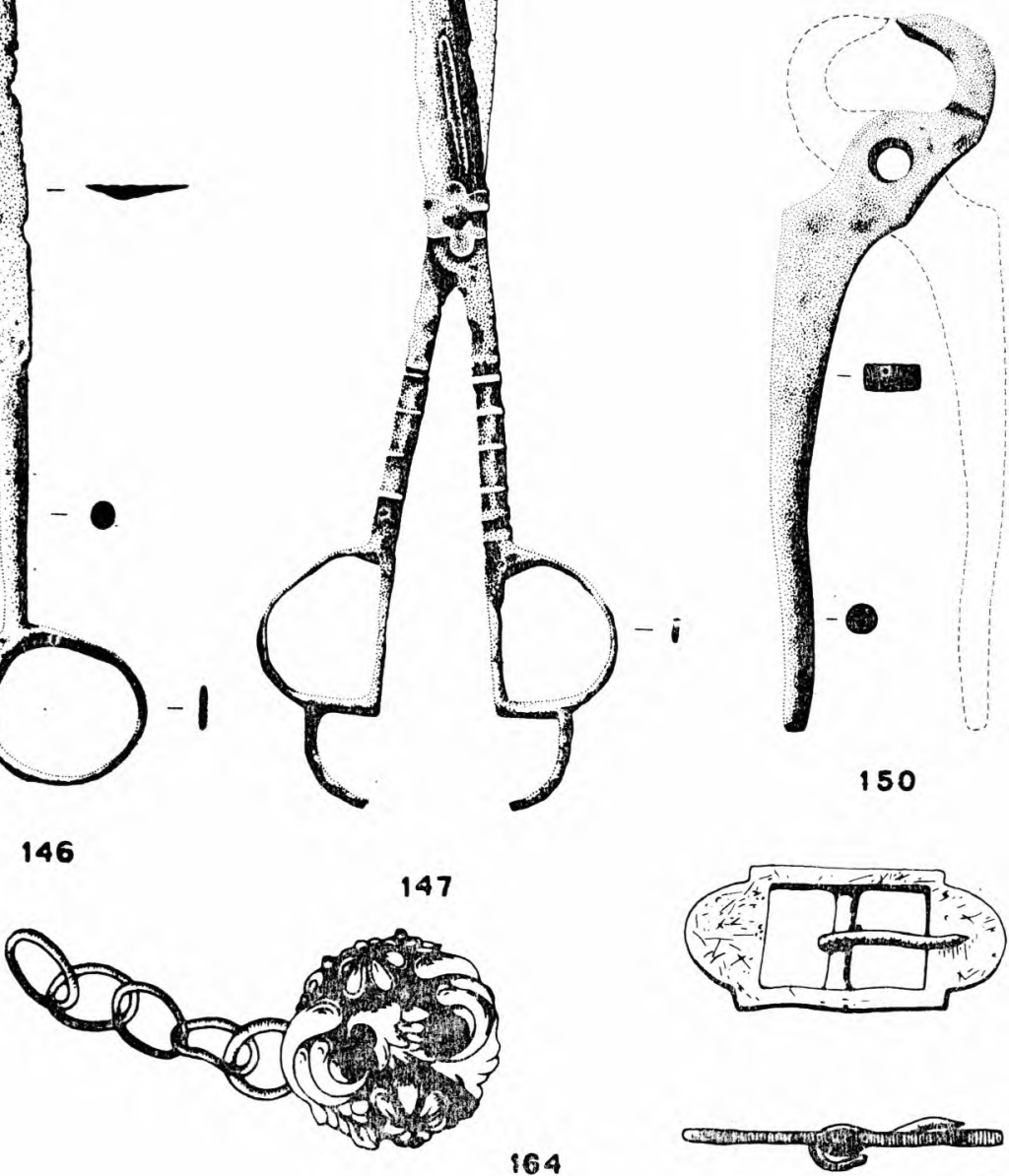

$\$ 64$
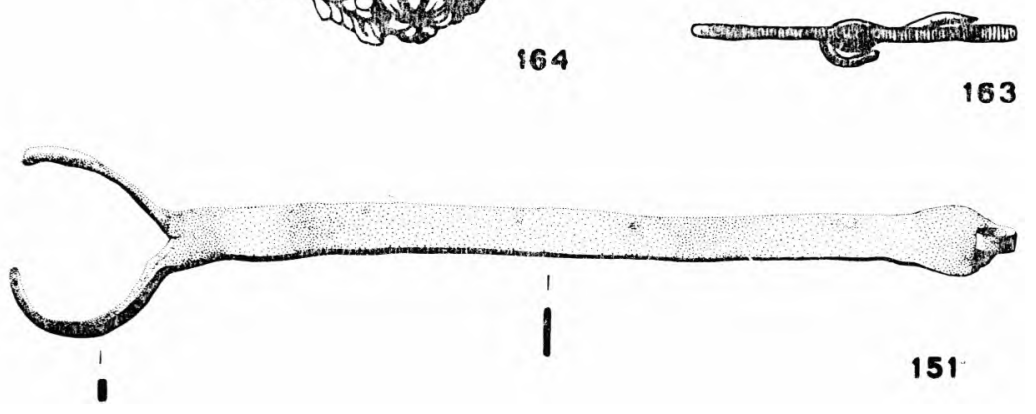

Esc. 2:3 

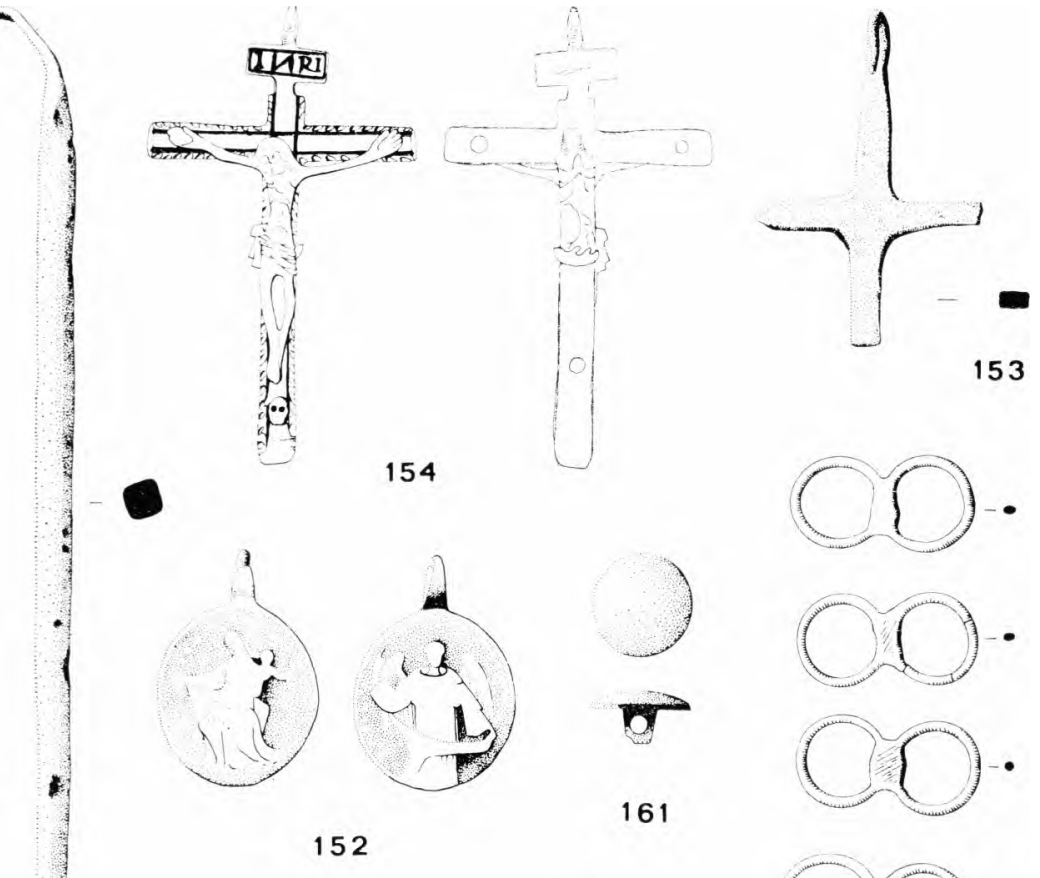

152
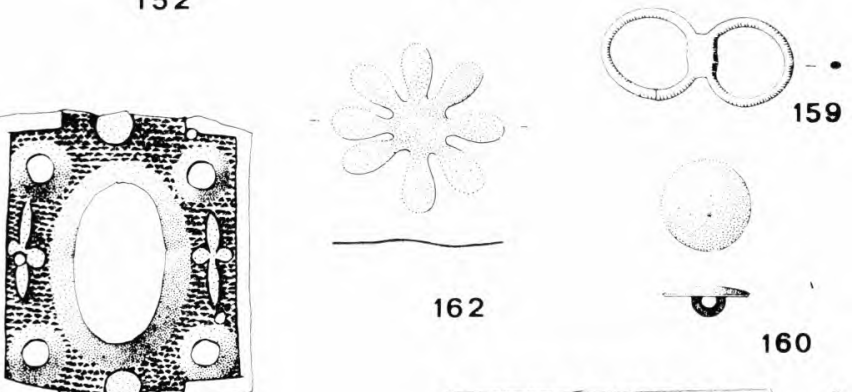

159

149
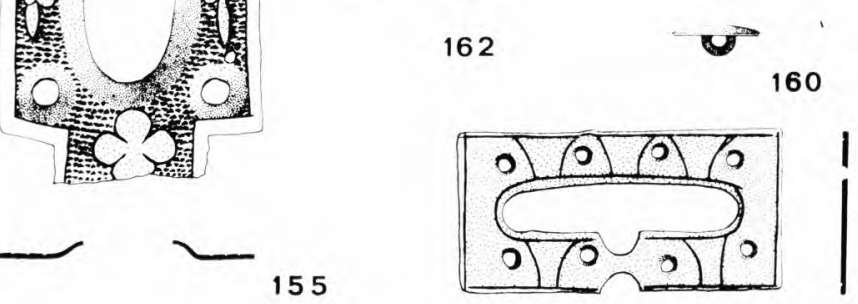

157
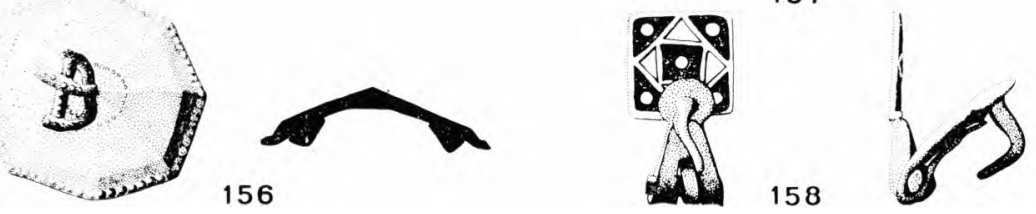

Esc. $2: 3$ 